Chapter 3

\title{
CXCR4 in Central and Peripheral Lymphoid Niches - Physiology, Pathology and Therapeutic Perspectives in Immune Deficiencies and Malignancies
}

\author{
Christelle Freitas, Alexandre Bignon, \\ Karl Balabanian and Ali Dalloul \\ Additional information is available at the end of the chapter
}

http://dx.doi.org/10.5772/58699

\section{Introduction}

The discovery of the cell-attracting chemokine Stromal cell Derived Factor 1 (SDF-1)/CXCL12 some twenty years ago and its ligand CXCR4 spurred tremendous research interest and generated an abundant literature reflecting the role of CXCR4 in various aspects of physiology and pathology, extending much beyond the role of CXCR4 as a co-receptor for Human Immunodeficiency Virus (HIV) on human T-cells [1-3].

Indeed, CXCL12 and CXCR4 are expressed in a complementary pattern during embryogenesis and are needed for endodermal migration $[4,5]$. In addition, CXCL12 is induced by hypoxia through the transcription factor hypoxia-inducible factor 1 (HIF1) and accordingly stimulates CXCR4-positive stem cells that locate within cellular hypoxic niches [6, 7].

These features explain the lethal phenotype of Cxcr4 null-mutated mice, hence the need for cell-specific conditional deletion models to be able to decipher its physiological functions [8]. This sharply contrasts with knockouts (KO) for most other chemokine/chemokine receptor pairs, which are almost viable throughout the adult life and point to the uniqueness of the CXCL12/CXCR4 pair in physiology. Note however that another CXCL12 receptor, ACKR3 (CXCR7) has been described, it may therefore overlap with the functions of CXCR4 [9-11]. As the physiological role of ACKR3 is not yet fully understood, its description is beyond the scope of this review. 
Although CXCR4 signaling governs many aspects of stem cell development during embryonic and adult life, it also plays a role in the proper homing and migration of mature lymphocytes within the bone marrow and peripheral lymphoid organs. It also regulates B-cell differentiation as discussed later.

From a paradigmatic point of view, upon engagement with its ligand, three processes namely desensitization (homologous and heterologous), internalization, and degradation regulate CXCR4. The homologous desensitization, or becoming refractory to continued stimulation, involves the recruitment of G-protein-coupled receptor kinases (GRK) that promote the recruitment of $\beta$-Arrestin which prevents coupling of receptor to new $G$ protein and initiate endocytosis in clathrin-coated pits [12]. The receptor may then be recycled or degraded following ubiquitination by the E3 ubiquitin ligase AIP4 [13]. Another mechanism of heterologous desensitization is mediated by the activation of second messenger dependent protein kinases such as protein kinase A and C (PKA and PKC) [14].

Abnormal expression and/or activity of CXCR4 due to an over stimulation or inhibition of transcription or internalization may therefore impact on several aspects of haematopoiesis and adaptive immune response, hence immune deficits and lymphoid neoplasms. A paradigmatic disease in this respect is the WHIM syndrome in which CXCR4 is mutated and displays anomalous internalization and signaling properties [15]. More recently, one third of patients with Waldenström's macroglobilinemia, a disorder induced by an IgM-producing plasmacytoma, were shown to harbour the WHIM syndrome mutation [16].

Altogether understanding the molecules that regulate CXCR4 expression and/or activity in leukocytes is a very active area of investigation inasmuch as CXCR4 expression can be regulated by the processing of CXCL12 either by cleavage or binding to glycosaminoglycans (GAGs) within extracellular matrix [17, 18]. Engagement of either the T-cell or the B-cell receptor (TCR or BCR) on lymphocytes can down regulate cell surface CXCR4 expression pointing to cross talks between CXCL12/CXCR4 axis and other chemokine independent pathways $[19,20]$.

These findings already translated into clinical applications with the invention of the first CXCR4 antagonist, AMD3100 and as our knowledge widens will be followed by other drugs aimed at directly or indirectly regulating CXCR4 expression and signaling, for multiple medical purposes [21].

The physiological role of chemokine receptors is still a matter of intense research and attempts to generate pharmacological antagonists of these receptors are numerous [205]. Among these receptors, CXCR4 is the one with the most successful implications in medicine, especially in the fields of immunology and haematology. Our goals were therefore to summarize or current knowledge on CXCR4 in these fields. This review describes our current knowledge on CXCR4 involvement in the development of lymphoid progenitors (chapter 2), B-cells (chapter 3), Tcells (chapter 4) and as recently described, in NK-cells (chapter 5). We describedon one hand, pathological lymphoid disorders with quantitative abnormalities of CXCR4 including Idiopathic T-cell lymphocytopenia (chapter 7), chronic lymphocytic leukaemia (chapter 8), and 
solid tumours (chapter 9); and on the other hand, pathologies with qualitative mutations of CXCR4 including the WHIM Syndrome (chapter 6) and Waldenström's Macroglobulinemia (chapter 8).

\section{CXCR4 and haematopoiesis}

The CXCL12/CXCR4 axis is pivotal in the survival of Hematopoietic Stem Cells (HSC) and early-committed progenitors, in their mobilization from the bone marrow to the peripheral blood and migration back from the blood to the bone marrow. This later process continuously seeds suitable niches from the bone marrow with functional HSC thereby allowing the maintenance of haematopoiesis. Hematopoietic stem and progenitors expressing CXCR4 interact with CXCL12-expressing stromal cells within niches thus delivering survival, and mobilization signals to multipotent and committed progenitors.

The sequential appearance and disappearance of hematopoietic activity is notably governed by the CXCL12/CXCR4 axis and Very Late Antigen-4/Vascular cell adhesion molecule-1 (VLA4/VCAM-1) interactions [8, 22]. The role of CXCL12/CXCR4 interaction is needed for proper haematopoiesis throughout life as shown by induced deletion of Cxcr4 in adult mice [23]. As mentioned above, the mechanisms of stem cell mobilization from the bone marrow are complex and regulated by factors of homing and adhesion to and within the niche. Adhesion is a multistep process that involves selectin-mediated tethering and rolling on stromal/endothelial cells followed by activation and ultimately firm adhesion mediated by integrins [24]. CD34 ${ }^{+}$cells express both CD162 a sialomucin that binds all selectins and VLA4 $[25,26]$. Of interest in this respect, CXCL12 enhances integrin activation and at least in vitro, E-selectin thereby promoting adhesion of $\mathrm{CD} 34^{+}$cells to the niche under flow, which allows their subsequent transmigration through endothelium [27, 28]. CXCL12 synergizes with Granulocyte colony-stimulating factor (GCSF) which activate the VLA4-ligand VCAM1and Vascular endothelial growth factor (VEGF) which activate both VCAM1 and E-selectin [28-30]. These findings were also supported by injection of antibodies and several $\mathrm{KO}$ mice models, and most convincingly by grafting human $\mathrm{CD} 34^{+}$cells into severe combined immunodeficiency mice [31]; this work demonstrated the dependency of CD34 $4^{+}$cell engraftment on CXCR4, the expression of which is unregulated by Stem cell Factor (SCF) [32]. Altogether, these findings demonstrated that CXCR4 signaling is required for stem cells to migrate, survive and differentiate into dedicated bone marrow niches. Studies dealing with effects of CXCR4 on the cell cycle on HSCs are contradictory. Some indicate that CXCR4 is required for the quiescence of primitive HSCs whereas others pointed a synergy between SCF/Kit-ligand and CXCL12 for the proliferation of CXCR4 $4^{+}$progenitors $[23,33,34]$. Indeed, CXCR4 expression is higher in the most primitive $\mathrm{CD} 34^{+} \mathrm{CD} 38$-progenitors and CXCL12 induced CD34 ${ }^{+}$cell proliferation in synergy with SCF or thrombopoietin TPO in vitro, further, cycling CD $34^{+}$cells may produce CXCL12 which protects them from apoptosis in an autocrine /paracrine manner $[35,36]$.

SCF and CXCL12 synergize for the maintenance of Kitand CXCR4 expressing HSC; this is highlighted by the finding that perivascular SCF expression pattern is very similar to that of 
CXCL12 in bone marrow stromal cells especially in the perivascular niche [37]. This also is in agreement with the reported localization of the most primitive HSC adjacent to sinusoidal blood vessels [23, 38-40]. Most HSC are in contact with CXCL12-abundant reticular (CAR) cells mostly located around sinusoidal endothelial cells or near the endosteum [23]. Recent outstanding data from the groups of Morrison and Nagasawa using conditional deletion of $\mathrm{Cxcl12}$ in various stromal cells from the bone marrow redefined the HSC niches [37, 41]. These data demonstrate that the most primitive $\mathrm{Cxcr} 4^{+} \mathrm{HSC}$ reside in a perivascular region in close contact with endothelial cells and perivascular cells whereas early lymphoid progenitors occupy an endosteal niche in close contact with osteoblasts. This also implies that bone marrow progenitors directly interact with Cxcl12-expressing stromal cells and do not respond to a Cxcl12 gradient, but that $\mathrm{Cxcr} 4$ expression and responsiveness of various progenitors to Cxcl12 dictate their fate within the bone marrow. It is indeed striking that CXCR4 signaling mediates quiescence in primitive HSC whereas it induces the proliferation of early B-cell progenitors [8, 33]. Thus genetic ablation of the Cxcr4 transcript relieves HSC from quiescence and allows them to differentiate and migrate to the blood, as they fail to home back into their bone marrow niches, these cells ultimately loose their self renewal capacity and ability to restore blood lineages upon grafting into syngeneic recipient.

Interference with the CXCL12/CXCR4 axis, was initially thought to prevent the binding and entry of HIV in T-cells using CXCR4 antagonist AMD3100, but this approach was not used in clinics until now [42]. However, a clinical trial is underway with the CXCR4 allosteric antagonist AMD11070 [43].

Nevertheless, interfering with CXCL12/CXCR4 axis by means of a pharmacological and reversible ligand of CXCR4, AMD3100, allows human HSC to leave their niche and migrate to the blood were they can easily be collected by apheresis in order to be grafted to a recipient (allograft) or to the donor himself (auto graft) following chemotherapy. AMD3100 is currently approved by the Food and Drug Administration (FDA) to induce in combination with GCSF the mobilization of human HSC [44]. Of interest, injection of GCSF to induce stem cell mobilization has long been used for clinical transplantation although its mechanism remained poorly understood [45]. Among the mechanisms evoked for GCSF action, is the degradation of CXCL12 by neutrophil elastase in parallel with up regulation of CXCR4 [46]. As CXCL12 has a very short half-life time ( $1 \mathrm{~min})$, it is very sensitive to degradation by cleavage of its $\mathrm{N}$ terminal domain [47].

In brief, CXCR4 is expressed on the most primitive and more committed hematopoietic progenitors and signals through interactions with CXCL12-expressing stromal cells in various bone marrow niches. CXCR4-mediated signaling results in distinct responses depending on the cell type (for instance quiescence $v$ s proliferation), as also shown by predominant HSC and B-cell defects in Cxcr4-null mice, and neutrophil abnormalities in WHIM syndrome. It therefore remains to understand how CXCR4 is modulated and why progenitors behave differently following CXCR4 engagement. It is also unclear how progenitors move from one niche to another following CXCR4 engagement. Solving these challenges in the next years will undoubtedly teach us more in the fields of haematopoiesis and immunology. 


\section{CXCR4 and B-cell development}

\subsection{Early steps of B-cell development}

Contrary to HSC, where CXCR4 signaling promotes survival and quiescence (see above), CXCR4 signaling in B-cell precursors promotes cell growth; this property led to the discovery of SDF1/CXCL12 [1]. The Cxcl12-null mice model established that Cxcl12 was necessary for Bcell lymphopoiesis in foetal liver and bone marrow, in addition to be necessary for bone marrow myelopoiesis [8]. This phenotype was close to that of Cxcr4 null-mutated mice and is likely due to the inability of B-cells from the blood to home into bone marrow or foetal liver $[48,49]$. Homing of B-cell precursors into specific bone marrow niches is indeed dependent on Cxcl12/Cxcr4 interactions [50]. Further experiments using adoptive transfer of cells from $\mathrm{Cxcr}^{--}$animals, established the need for Cxcr4 expression by B-cell progenitors throughout adult life in order to home into the bone marrow [51]. Although myeloid lineages were also affected, the defect was predominant on the B-cell lineage further pointing to the dependency of B-cells towards the CXCL12/CXCR4 axis. As for HSC, B-cell precursors depend on VLA4/ VCAM1, and CXCR4/CXCL12 interactions for adhesion to stromal cells [52, 53].

Cxcl12-abundant reticular cells (CAR) are scattered throughout the bone marrow and in close contact with HSC and B-cell precursors [23, 54]. Recently, the redefinition of bone marrow niches established that early lymphoid precursors are in close contact with osteoblasts while committed B-lineage progenitors are in contact with the perivascular niche [37, 41]. Of interest, the ability of osteoblasts to support the differentiation of primitive HSC towards all stages of B-cells has been reported [55]. Furthermore, this differentiation appeared dependent on VCAM-1, CXCL12 and G protein $\alpha$ i subunit expression by osteoblasts [55, 56]. It should be mentioned that the expression of CXCR4 is sinusoidal in the B-cell lineage being highest in pre-B-cells and decreasing as cells develop in immature B-cells, and finally increases in mature B-cells; however the response of mature B-cells to CXCL12 remains poor despite their high CXCR4 expression [57]. Thus, as for HSC, B-cell precursors are highly sensitive to CXCL12; this is possibly linked to intrinsic properties of the cells such as sustained activation of the focal adhesion kinase pathway contrary to mature B-cells [53]. Altogether, the fine-tuning of CXCR4 response during B-cell maturation is complex and not only mediated by the regulation of CXCL12 production and proteolysis or by CXCR4 transcription and trafficking, but also by exogenous factors such as local production of CCR5 ligands that induce heterologous desensitization of CXCR4 to CXCL12 [58].

As discussed below, mutant mice harbouring the WHIM Syndrome linked Cxcr4 mutation display abnormal B-cell differentiation at the early B-cell committed progenitors stages combined to anomalous B-cell positioning within secondary lymphoid organs [59]. This points to the role of CXCR4 in mature B-cells peripheral compartmentalization. 


\subsection{B-cell homing and positioning within secondary lymphoid organs and regulation of CXCR4 expression by BCR signaling}

Following B-cell development in the bone marrow, transitional B-cells home into secondary lymphoid organs to become follicular naive B-cells that constitute a B-cell zone, called primary follicle, distinct from the T-cell one. B-cells use CCR7, CXCR4 and CXCR5 receptors to migrate from the blood into SLO [60, 61]. CXCR5 ${ }^{+} B$-cells are attracted and organize themselves around CXCL13-expressing follicular dendritic cells and marginal reticular cells at the periphery, whereas T-cells express CCR7 and are attracted by CCL19-and CCL21-producing reticular cells [62]. Following antigen-specific T-cell activation, T-cells down regulate CCR7 and move towards B-cell follicles. In parallel antigen-activated B-cells keep their CXCR5 expression unaltered while up regulating that of CCR7 thereby migrating towards the T-cell zone. Upon T-B encounter, antigen-specific B-cells then proliferate to constitute the dark zone of the germinal centre. These large cells so called centroblasts undergo Immunoglobulin (Ig) gene class-switch recombination, due to CD40/CD154 interactions on B-and T-cells respectively [63]. Class-switch recombination is also a prerequisite for B-cells to undergo somatic hyper mutation of the hyper variable regions of Ig genes, these random mutation process leads to antibody diversity [64]. Centroblasts constitute the dark zone and are CXCR4 $4^{+/ h i}$. As centroblasts are promoted they down regulate CXCR4, enter a quiescent state and constitute the light zone made of $\mathrm{CD} 23^{+} \mathrm{CD} 83^{+} \mathrm{CXCR} 4^{-/ 10}$ differentiated B-cells called centrocytes and are selected by antigen-presenting cells, so that B-cells with high affinity against antigen are positively selected for survival whereas low-affinity cells die in situ $[65,66]$. Centrocytes ultimately give rise to plasma cells (PC) or to memory B-cells. B-cell differentiation in PC precursors also called plasmablasts, requires a synchronous up regulation of CXCR4 and down regulation of CXCR5, however migration of plasmablasts into splenic red pulp or lymph node medullary sinuses may not depend on CXCR4 expression inasmuch as mice with invalid CXcr4 in adult B-cells display PC in these respective anatomic sites [67-69]. A likely hypothesis is that CXCR4 is instead needed for long-lived PC survival in bone marrow niches and thatVLA4 interaction with VCAM1 is necessary in this respect $[70,71]$ whereas migration of antibody-producing cells into the bone marrow depends on the sphingosine-1 phosphate and its receptor S1P1 [68]. Finally, an unanswered and interesting question is whether long-lived PC and B-cell progenitors compete for the same bone marrow niches.

Thus CXCR4 expression is sinusoidal in mature B-cells and tightly regulated within the secondary follicle intuitively suggesting that anomalous expression or signaling of CXCR4 may lead to B-cell defects or malignancies.

It is well known that CXCR4 expression is regulated directly by interactions with CXCL12 and indirectly by BCR signaling. CXCL12 interaction with CXCR4 induces CXCR4 inactivation on T-and B-cells and myeloid cells as well, so it is a general mechanism at least on mature cells that lead to CXCR4 phosphorylation on its intracytoplasmic C-terminal tail, leading to G protein uncoupling and CXCR4 internalization [20,72, 73]. As for most chemokine receptor which are G-protein-coupled receptors, binding of CXCR4 with its ligand induces conformational modifications and secondary activation of G-proteins and further intracellular recruitment of G-protein-coupled-receptor kinases (GRK) that phosphorylate CXCR4 on Ser/Thr 
residues and recruit $\beta$-arrestins resulting in CXCR4 desensitization and finally its internalization [14]. CXCR4 is internalized and its surface expression down regulated following BCR activation or CXCL12 binding. Both signaling pathways induce CXCR4 phosphorylation on Ser residues albeit on distinct residues [20]. In fact, the migratory B-cell response to CXCL12 depends on both intrinsic factors and CXCR4 expression; indeed naive and memory B-cells are more sensitive to CXCL12 than germinal center B-cells in this respect [74]. The inhibition of CXCL12-mediated chemotaxis following BCR engagement depends on PKC but not on $\mathrm{Ca}^{2+}$ due to CXCR4 internalization [20).

In conclusion, CXCR4 expression in B-cell lineage cells depends on CXCL12 expression at the pro/pre B-cell stages and PC that lack functional BCR, whereas it also depends on the BCR signal strength at more mature stages.

\section{CXCR4 and T-cell development}

Early thymic progenitors $\mathrm{cKit}^{+}$which reside in the thymic double negative DN1 fraction differentiate from common lymphoid progenitor and migrate from the bone marrow to the thymus through the blood and invade the epithelial rudiment at the cortico-medullary junction through post capillary venules where they loose progressively non-T-cell differentiated capacity and become fully T-cell committed as also described in human thymocytes [75-79]. These DN thymocytes make some $2 \%$ of thymocytes and are further divided in differentiation stages based on CD44 and CD25 expression [80]. CD44 CD25-DN1 cells differentiate in $\mathrm{CD} 44^{+} \mathrm{CD} 25^{+} \mathrm{DN} 2$ cells following migration into the subcapsular zone, DN2 differentiate in CD44-CD25 DN3 cells and the later in CD44-CD25 cortical DN4 cells. In turn DN4 differentiate in $\mathrm{CD}_{4}^{+} \mathrm{CD} 8^{+}$double positive DP thymocytes that acquire surface CD3 and move toward the inner cortex [81]. Only two chemokines, CXCL12 and CCL25/thymus-expressed chemokine TECK are expressed in the thymic cortex namely by cortical epithelial thymic cells [82-84]. The CXCL12/CXCR4 axis is mandatory for retaining human double positive (DP) thymocytes in the cortex. In addition, in mice lacking Cxcr4 on thymocytes displayed defective DN migration to the cortex and defective DN to DP transition [82, 85-87]. DN migration can indeed be inhibited by AMD3100 [85, 88]. In the medulla, CCR7 promotes migration of mature thymocytes from the cortex. Thus, two opposing chemokine gradients regulate thymocyte migration from the cortex to the medulla.

TCR $\beta$ selection starts at the DN stage and DN3 cells express pre-TCR made of a pre-TCR $\alpha$ chain associated to TCR- $\beta$ chain. These cells are selected positively by interactions with stromal cells in the cortex and CXCR4 is crucial for this process. Indeed, it is functionally associated with the pre-TCR and needed to activate phosphatidyl inositol 3-kinase (PI3K) and Notch pathway, the later which is mandatory for T-cell differentiation [86, 87, 89, 90]. In brief, DN thymocytes expand and differentiate in the cortex due to migration retention and survival signals dependent on CXCR4, and as for HSC, CXCR4 activation up regulate adhesion molecules integrin- $\alpha 4 \beta 1 /$ VLA4 [91, 92]. 
Thus CXCR4 plays a crucial and non-redundant role in thymic progenitors positioning in the cortex and in pre-TCR-mediated survival signals, the failure of which resulted in developmental arrest at the DN stage. Of interest, mice carrying a WHIM Syndrome heterozygous Cxcr4 mutation display abnormal thymic maturation [59]. Once positive selection of DP thymocytes and negative selection of $\mathrm{CD} 4^{+}$and $\mathrm{CD}^{+}$single positive thymocytes has been achieved, these cells leave the thymus to seed secondary lymphoid organs. Naive T-cells do not rely on CXCR4 for thymic egress and to home into T-cell zones. However CXCR4 is needed for T-cell extravasation through high endothelial venules and entry into the lymph nodes [93].

As for the BCR, TCR engagement or signals that mimic PKC activation such as phorbol esters result in the phosphorylation and internalization of CXCR4 in T-cells, whereas infections with human herpes viruses HHV-6 or-7 down regulateCXCR4 transcription [72,94]. TCR-induced CXCR4 down modulation may therefore help T-cells stay at the site of self-antigen encounter by dendritic cells (DC) in the thymus in order to undergo negative selection in the medulla. Similar mechanism may operate in secondary lymphoid organs during presentation of antigens by DC. Of interest CXCR4 may increase the stability of the T-antigen-presenting cell (APC) immunologic synapses (IS) necessary for successful T-cell activation [95]. Interestingly, upon CXCL12 stimulation, a physical association between CXCR4 and TCR was described and promote TCR signal transduction. This association is responsible for prolonged extracellular signal regulated kinase activity, increased intracellular calcium ion concentrations, robust activator protein-1 transcriptional activity, and SDF-1 $\alpha$ costimulation of cytokine secretion. These pathways mediate costimulation of cytokine secretion by activated T-cells [96].

Following antigen encounter, naive T-cells differentiate in $\mathrm{CD} 4^{+}$or $\mathrm{CD} 8^{+}$memory T-cells that home into the bone marrow which is a survival site for memory T-cells [97, 98]. However CXCR4 does not seem to be necessary for the retention and survival of memory T-cells, as survival is mostly dependent on IL7 [99, 100].

In conclusion the physiological role of CXCR4 in T-cell development and functions predominates on thymic progenitors although impaired peripheral T-cell responses in WHIM syndrome and Idiopathic CD4 ${ }^{+} \mathrm{T}$-cell Lymphocytopenia suggest a role of CXCR4 on peripheral Tcells.

\section{CXCR4 and NK-cell development}

Natural killer (NK) cells are lymphocytes of the innate immune system that are involved in the early control of infections by viruses and other intracellular pathogens. NK cells can be identified by expression of the activating NK receptor NK1.1 associated with the absence of T-cell CD3 receptor complex. Based on the membrane expression of the tumour necrosis factor superfamily member CD27 and the integrin CD11b, four maturation stages can be identified: CD11b ${ }^{\text {low }} \mathrm{CD} 27^{\text {low }}$ ("double negative"), which likely encompass precursors, $\mathrm{CD} 11 \mathrm{~b}^{\text {low }} \mathrm{CD} 27^{\text {high }}$ ("CD11b low"), CD11b ${ }^{\text {high }} \mathrm{CD} 27^{\text {high }}$ ("double positive"), and CD11b $\mathrm{b}^{\text {high }} \mathrm{CD} 27^{\text {low }}$ ("CD27 low") [101, 102]. These NK-cell subsets display heterogeneous distribution in lymphoid organs. The bone marrow plays a pivotal role in NK-cell development. NK-cell differentiation in the bone 
marrow is associated with coordinated and tightly regulated changes of both expression and activity of distinct GPCRs including CXCR4. Indeed, CXCR4 is highly expressed on NK precursors but it gradually declines during maturation [103]. Conversely, expression of CXCR3, CCR1, CX ${ }_{3}$ CR1 and S1P5 (Sphingosine-1-phosphate receptor 5) progressively increase with NK-cell maturation [104, 105]. CXCR4 and S1P5 appear as master regulators of NK-cell retention in, and egress from, the bone marrow. The exit process is obviously required for ensuring immunosurveillance. CXCR4 retains NK cells in the bone marrow parenchyma, whereas S1P5 promotes their exit from this organ through sinusoids. Using S1p5-null mice and knockin (KI) mouse model in which Cxcr4 cannot be desensitized, Mayol et al have recently showed that NK-cell exit from the bone marrow requires both Cxcr4 desensitization and S1p5 engagement by their corresponding ligands namely Cxcl12 and S1p, which are produced in the bone marrow and the bloodstream respectively [103]. In the bone marrow, CXCL12 is detected in different niches including the endosteal one and CAR cells as well [46, 106]. A recent study indicates that NK cells are found in close contact to CAR cells that also produce IL-15, another master regulator of NK-cell homeostasis [107]. Another work conducted by Sciumè and collaborators has involved the integrin chain $\alpha 4$ and the Fractalkine/CX ${ }_{3} \mathrm{CL} 1$ receptor $\mathrm{CX}_{3} \mathrm{CR} 1$ in the positioning of mature NK cells in the sinusoidal compartment [104]. Once in the blood, the S1P concentration increases and S1P5 responsiveness decreases [108]. This responsiveness is recovered in the lymph nodes to allow NK-cell exit via lymphatics in a CXCR4-independent manner. The mechanism controlling NK-cell exit from the human bone marrow is likely to be similar to the one reported in the mouse counterpart. Several lines of evidence support this assertion. First, the absolute number of NK cells is deeply decreased in the peripheral blood of some WHIM syndrome patients that harbour a gain-of-CXCR4function mutation [109]. Second, CXCR4 has been shown to retain human NK cells in the bone marrow and spleen of immunodeficient mice reconstituted with human immune system [110]. Finally, S1P5 was reported to be unregulated during human NK-cell differentiation [105].

\section{CXCR4 in the WHIM syndrome}

The WHIM syndrome (WS) is a rare immunological disorder characterized by the presence of warts $(\mathrm{W})$, hypogammaglobulinemia $(\mathrm{H})$, bacterial infections (I) and myelokathexis (M) meaning an abnormal retention of pro-apoptotic neutrophils in the bone marrow [111]. WS is an inherited pathological disorder with an autosomal dominant transmission. The WS estimate incidence was of 0.23 per million births but the prevalence is $<1 / 1000000$. In fact, there are less than 60 documented cases in the world [112].

Inherited heterozygous autosomal dominant mutations of the CXCR4 gene, which result in the truncation of the carboxyl-terminus of the receptor leading to a defect of CXCR4 inactivation, were found to be associated with the WS [113]. The disorder is clinically and genetically heterogeneous, since hypogammaglobulinemia and verrucosis were absent in some cases, and individuals with isolated myelokathexis were found to be "wild type" for the CXCR4 gene [114]. As described previously, CXCR4 is expressed in hematopoietic cells. Consequently, the 
lack of CXCR4 inactivationis expected to generate significant immune and haematological disturbances [14].

Patients with WS exhibit a marked lymphopenia suggesting either a central defect of leukocyte differentiation in the bone marrow and the thymus or a peripheral defect such as an increase in apoptosis. Morphological analysis of bone marrow was performed in some patients; it evidenced an abnormal morphology of neutrophils called myelokathexis and an increase in neutrophil counts [111]. Furthermore the analysis of a bone marrow sample from one patient failed to detect abnormalities in lymphoid precursors and in immature and mature B-lymphocytes [115].

Biological features of WS include hypogammaglobulinemia, involving IgG. As expected, hypogammaglobulinemia combined to neutropenia in WS patients results in infections especially of encapsulated bacterias. Interestingly, infections transiently increase the number of neutrophil counts in the blood suggesting that neutropenia is caused by lack of neutrophils egress rather than to a defect in production. Patients also present recurrent pneumonias, sinusitis, urinary tract infection and skin infections among others. Strikingly, WS patients display high susceptibility to human papilloma virus (HPV) leading to skin lesions such as warts on hands, feet and trunk, genital and anal condylomas and mucosal lesions which often progress to carcinomas [116]. In two patients carrying the heterozygous CXCR4 1013 mutation, CXCR4 failed to internalize on lymphocytes upon stimulation. In PBMC, refractoriness of CXCR4 for desensitization and internalization led to an enhanced CXCL12-promoted chemotaxis [114]. Thus the lack of CXCR4 inactivation is associated with a gain of function of the receptor at least based on migration capacity criteria.

Despite lymphopenia and hypogammaglobulinemia, WS patients immunized with tetanustoxoid produce normal amounts of antibodies against tetanus-toxoid 10 weeks after immunization. However, no specific antibodies were found one year after immunization suggesting a defect in long-lived PC and/or in memory B-cell response in WS [115].

There are currently no specific treatments for WS patients, albeit symptomatic use of GCSF and intravenous immunoglobulins (Ig) combined to anti-infectious agents is of some help [116], however CXCR4-targeted therapy is promising as described below.

In order to better understand this pathology, to characterise lymphoid differentiation and haematopoiesis defects in WS, we sought to generate an animal model. Balabanian et al generated a KI mouse strain that harbours a WS-associated heterozygous mutation of the Cxcr4 gene (i.e., $C x c r 4^{+/ 1013}$ ) to analyse the impact of Cxcr4 desensitization on leukocyte homeostasis [59]. These mice display a severe lymphoneutropenia. As in patients, CXCR4 failure to internalise doesn't lead to an increase in receptor expression in leukocytes in eitherbone marrow, thymus, spleen and blood. Moreover, all tested leukocyte subsets from $\mathrm{Cxcr}^{+/ 1013}$ mice, displayed increased sensitivity to Cxcl12-promoted chemotaxis compared to wild type mice as shown in blood T-and B-cells, and in DP, and SP thymocytes. Both frequency and absolute numbers of $\mathrm{CD} 19^{+} \mathrm{B}$-cells were slightly, but significantly lower in the bone marrow from $\mathrm{CxCr}^{+/ 1013}$ mice. In contrast to the myeloid series, leukocyte differentiation was altered in $\mathrm{CxCr}^{+/ 1013}$ mice. Indeed, the absolute number of pro/pre-B cells, and to a 
lesser extent of immature B-cells, was reduced in $\mathrm{Cxcr}^{+/ 1013}$ mice. Therefore, the alteration of early B-cell development in $\mathrm{Cxcr}^{+/ 1013}$ mice was not associated with enhanced cell death. Regarding thymic differentiation, the absolute number of each thymic subset (from progenitors to mature SP thymocytes) was significantly decreased in $\mathrm{Cxcr}^{+/ 1013}$ mice. Together, these findings reveal that altered Cxcr4 $4^{1013}$-driven development of B-and T-cells leads to chronic circulating lymphopenia.

Regarding the periphery, the absolute number of each blood leukocyte subpopulation was significantly reduced in $\mathrm{Cxcr}^{+/ 1013}$ mice. Serum levels of natural IgA were similar in nonmanipulated CXCr4 ${ }^{+/ 1013}$ and WT mice, whereas IgM and IgG concentrations increased in $\mathrm{C} x \mathrm{cr}^{+/ 1013}$ mice contrary to patients as mentioned above. In parallel, mature T-and B-cells were abnormally compartmentalized in the periphery, with fewer primary follicles in the spleen and absence in lymph nodes, mirrored by an unfurling of the T-cell zone. These mice provide a model to decipher the role of CXCR4 desensitization in the homeostasis of B-and T-cells and to investigate which biological abnormalities of patients may be reversed by dampening the gain of CXCR4 function [59]. As mentioned above (chapter 4) CXCR4 may increase the stability of the T-APC interactions and is necessary for optimal T-cell activation [95]. Indeed, recent data demonstrated that WHIM-CXCR4-expressing retrogenic T-cells inhibits the formation of long-lasting T-APC interactions confirming the role of CXCR4 in the stability of T-APC Immune Synapse. Such anomalous synapse formation likely results in the failure to respond to vaccinations with the absence of specific antibody one year after vaccination observed in WS patient [117]. Thus, it will be interesting to investigate if there is an optimal adaptive immune response in these mice. In addition, the discovery of a mouse papillomavirus (MusPV) rendered possible to analyse HPV-infected $C x c r 4^{+11013}$ mice [118], as done in nude mice [119].Finally our mice will also be useful to test new drugs including molecules that target CXCR4.

AMD3100 (plerixafor) a selective and competitive antagonist of CXCR4 appears to be a potential treatment for patients with WS, and clinical studies have been conducted accordingly. One study reported the effect of daily injections with increased concentrations of AMD3100 (0.02-0.24 mg/kg) in 3 adults with WS; an increase of white blood cells and of absolute lymphocyte, neutrophil and monocyte counts was observed in all patients. Furthermore white blood cells mobilization is higher with AMD3100 than with GCSF [120]. Another study showed that treatment with AMD3100 every 2-4 days in 6 patients resulted in prompt leukocytosis [121]. Mice carrying the heterozygous $\mathrm{Cxcr}^{+/ 1013}$ mutation, were also treated with AMD3100 or chalcone 4 that binds Cxcl12 and prevents signaling through Cxcr4. After single intraperitoneal injection of either AMD3100 or chalcone 4, the absolute numbers of total leukocytes in the blood of WT mice, including neutrophils, B and T cells was increased within 3 hours [59].Therefore, AMD3100 is able to reverse the pan leukopenia in WS mice and patients albeit transiently because of its short half-life. A more recent trial involving 3 WHIM patients treated with plerixafor subcutaneously twice daily for 6 months in combination with the Interferon- $\alpha$ inducer imiquimod, showed improvement in warts and in infections, albeit with partial restoration of Ig levels and vaccine responses [103]. 
To conclude, patients with WS have a gain of CXCR4 function, which leads to severe disorders of lymphocytes and neutrophils and hence of immune responses. How it affects mature T-and B-cells is still unclear. Undoubtedly, studies on homozygous and heterozygous mice and on the hematopoietic compartment will help understand the pathologies associated with CXCR4 dysfunction.

\section{CXCR4 in the Idiopathic CD4+Lymphocytopenia syndrome}

Idiopathic CD4+T-cell Lymphocytopenia (ICL) is a rare haematological disorder characterized by a profound and persistent $\mathrm{CD} 4^{+} \mathrm{T}$-cell defect, defined by an absolute $\mathrm{CD} 4^{+} \mathrm{T}$-cell count $<300$ cells $/ \mathrm{mm}^{3}$ with lack of HIV infection or other known immune defect or therapy associated with lymphopenia [122]. This clinical entity was defined in 1992 by the Centers for Disease Control and then some 258 cases have been reviewed in the literature [122, 123]. ICL patients often present life threatening opportunistic infections similar to those observed in acquired immunodeficiency (AIDS) syndrome. The most common infections in ICL are cryptococcal (Cryptococcus neoformans), genital HPV, non-tuberculous mycobacterial infections (Mycobacterium avium), in addition to progressive multifocal leukoencephalopathy [122, 124]. Malignancies are also common in ICL, including EBV-related B-cell lymphomas, Kaposi's sarcoma and as seen in the WHIM Syndrome, cervical or perineal neoplasias in the setting of long-term HPV infections [125-129]. In addition, autoimmune diseases (e.g. Sjögren syndrome) were also frequently reported [122].

The aetiology of ICL is unlikely to involve an infectious or environmental agent but may have a genetic basis as loss-of-function mutations have been reported in genes encoding regulators of the TCR diversity and signaling (i.e.Unc119, MAGT1 and RAG1) [130-132]. ICL is considered as a heterogeneous syndrome possibly encompassing different disorders sharing the common feature of reduced circulating $\mathrm{CD}^{+} \mathrm{T}$-cell counts. One issue is to determine whether the ICL results from a defective bone marrow production or thymic output, or an exacerbated peripheral consumption of CD4 ${ }^{+} \mathrm{T}$-cells, or any combination of central or peripheral defect.

The defective production of $\mathrm{CD} 4^{+} \mathrm{T}$-cell hypothesis is supported by a study reporting a regenerative failure of HSCs and lymphoid precursors in the bone marrow of ICL patients [133]. A work dealing with T-cell maturation has shown apparent restriction of the $\alpha / \beta$ and $\gamma /$ $\delta$ TCR in ICL suggesting a disturbed thymic T-cell maturation in ICL [134]. In support of the central defect hypothesis, CD34 ${ }^{+} \mathrm{HSC}$ s derived from one ICL patient carrying a hypomorphic missense mutation in the Recombination Activating Gene 1 (RAG1) were not able to repopulate

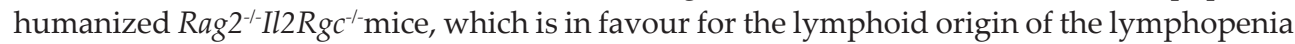
[132]. Finally, non-myeloablative allogeneic bone marrow transplantation in one patient was able to restore $\mathrm{CD} 4{ }^{+} \mathrm{T}$-cell numbers and functions [135].

In addition various works argue for an exacerbated peripheral consumption of CD4 $\mathrm{T}$-cells. Decreased T-cell responses as well as increased T-cell activation and apoptosis have been reported in ICL [136-138]. In terms of CD4 ${ }^{+}$T-cells activation, studies have reported enhanced propensity of ICL T-cells to undergo apoptosis, a process partially dependent on Fas and Fas 
ligand overexpression [137]. Markers for cell activation and turn-over, as indicated by HLADR, Ki-67 expression and BrdU labelling are also increased in CD4 ${ }^{+} \mathrm{T}$-cells and this was inversely correlated with blood CD4 ${ }^{+} \mathrm{T}$-cell counts [138]. In another report, abnormal CD4 ${ }^{+} \mathrm{T}$ cells cycling was associated with levels of plasma lipopolysaccharide resulting from microbial translocation [139]. Therefore, immune activation and preferential loss of naive T-cells in ICL could result from chronic and persistent stimulation by an unidentified pathogen [122]. Mechanistic studies have also pointed out a defective TCR signal transduction in ICL raising the possibility that persistent T-cell activation leads to defective TCR signaling and may contribute to T-cell depletion [130-132]. Increased levels of the homeostatic cytokineIL7 in the sera of ICL patients inversely correlate with those of blood naive CD4 ${ }^{+} \mathrm{T}$-cells and may reflect the triggering of a homeostatic response in order to restore normal CD4 $4^{+} \mathrm{T}$-cell counts $[133,137$, 140]. This accumulation of IL7 likely results from both a diminished consumption of the cytokine and a decrease of IL7 receptor $\alpha$ chain expression (CD127) on the reduced T-cell pool. Moreover the induction of phospho-STAT5 after IL7 stimulation was decreased in residual memory $\mathrm{CD}^{+}{ }^{+} \mathrm{T}$-cells of some ICL patients. These data suggest that high serum IL7 levels do not necessarily represent a compensatory response but may be further accentuating T-cell apoptosis and lymphopenia [141, 142]. In addition, while one study reported a successful therapy with IL2, decreased IL2 responses correlated with impaired IL7 responses, which may account for the loss of CD4 ${ }^{+}$T-cells homeostasis in ICL [142-144].

Regarding the CXCR4/CXCL12 axis, some studies demonstrated it role for T-cell production, homing, positioning and activation within secondary lymphoid tissues. Furthermore, alterations of CXCR4 expression or activity are likely to severely impact T-cell differentiation and trafficking. Thus, we hypothesized that expression or function of CXCR4 could be altered in ICL causing CD4 ${ }^{+}$T-cells alteration. Thus,ICL may mirror WHIM Syndrome as we observed decreased CXCR4 expression on CD4 ${ }^{+} \mathrm{T}$-cells in ICL. We contributed to the identification of a defect in CXCR4 expression at the surface of CD4 $4^{+} \mathrm{T}$-cells from 6 ICL patients with concomitant intracellular accumulation of CXCR4 and CXCL12. This suggested a defective intracellular routing of the chemokines/chemokines receptors complex. Analyses of CXCR4 fate following CXCL12 stimulation indicated that CXCR4 preserved its ability to internalize, but thereafter poorly recycled back to the plasma membrane of ICL T-cells. Altered membrane CXCR4 recovery resulted in a loss of CXCR4 function, as illustrated by the impaired CXCL12promoted chemotaxis of ICL CD4 ${ }^{+} \mathrm{T}$-cells [144]. These results were recently extended to 20 newly ICL patients and suggest that impaired membrane CXCR4 expression may contribute to the defective $\mathrm{CD} 4^{+} \mathrm{T}$-cell homeostasis in the periphery but also in the thymus.

Altogether, ICL is a complex disorder with impaired membrane CXCR4 expression in peripheral lymphoid populations and in progenitors, possibly explaining the downstream lymphocytopenia. Deciphering the reasons for such dysfunction will help us discover new molecular targets for immune cell therapy. In this context, we derived induced pluripotent stem cells iPSCs, from CD4 ${ }^{+} \mathrm{T}$-cells of an ICL patient; this will offer unprecedented opportunities to study T-cell differentiation in this disease. 


\section{CXCR4 in B-cell malignancies}

Chronic lymphocytic leukaemia (CLL) is the most common leukaemia accounting for some $30 \%$ of adult leukaemia's in western countries It is due to an accumulation of small B-cells in the blood, the bone marrow and secondary lymphoid organs. Although this accumulation reflects lack of apoptosis, CLL cells do proliferate and their mitotic index and telomere length correlate with the degree of malignancy as reflected by the Binet [145] or Rai [146] clinical staging or the mutational status of Ig hyper variable regions, currently the gold biological standard for prognosis in this disease [147-149]. Somatically Ig hyper mutated (M-CLL) is typically indolent whereas Ig unmutated (U-CLL) is more aggressive [150, 151]. The cellular origin of CLL has been intensively debated, however contrary to the prevailing view that CLL originate from memory/activated B2 B-cells, we favour the recent hypothesis that CLL B-cells originate from malignant transformation of $C D 5^{+} B$-cells [152]. Moreover both indolent and aggressive CLL originate from B-cells endowed with an auto reactive surface Ig which supports the hypothesis of a common molecular mechanism for both CLL types albeit occurring at two cellular differentiation stages [153].

CLL B-cells overexpress functional CXCR4 that may help B-cell to survive/proliferate and is associated with increased response to CXCL12 [154]. Indeed it has been noticed that CLL cells survive longer in vitro when cocultured with bone marrow stromal cells [155-157]. Interestingly survival mechanisms were linked to stimulation of CXCL12/CXCR4 and VLA4/VCAM axis [158-160]. This suggested that CLL cells are stimulated in protective microenvironments in the bone marrow or in secondary lymphoid organs and indeed proliferation centres with stromal cells and T-cells associated with CLL cells so called pseudo follicles were observed in these tissues [147, 161-164]. CLL cells in the blood are likely more sensitive to drugs than they are in lymphoid tissues.

Thus a new therapeutic strategy in CLL would be to down regulate or desensitize CXCR4 or disrupt CXCL12/CXCR4 interactions by AMD3100 on malignant B-cells in order to force them to leave their protective environments and undergo apoptosis in the bloodstream $[165,166]$.

As CLL are endowed with auto reactive surface Ig, they may be triggered repeatedly in vivo by auto antigens and BCR signaling is expected to down regulate CXCR4. Thus increased CXCR4 expression likely reflects the poor BCR signaling in vivo compared to that in normal B-cells; in addition CLL cells are surface Iglo. Indeed, CLL cells are anergic to anti-IgM stimulation, although U-CLL respond better in this respect than M-CLL in terms of proliferation and BCR signaling, and interestingly, U-CLL down regulate CXCR4 more efficiently than M-CLL upon sIg cross linking in vitro [167-169]. AMD3100 has been shown to potentiate Chemo/Immunotherapy in CLL in vitro [170]. This can be interpreted as either a blockade of the CXCR4 survival pathway or a help of CLL cells to detach from CXCL12 ${ }^{+}$stromal cells in SLO and move away from their protective microenvironment or both. These results need however to be reconciled with the finding that CXCR4 expression on CLL cells is lower in LO than it is in the blood [171].

As mentioned above (chapter 3), BCR-induced CXCR4 phosphorylation is PKC-but not $\mathrm{Ca}^{2+}-$ dependent [20]. Either CXCL12 interaction with CXCR4, or BCR engagement activates 
PI3kinase- $\delta$ and CAL101 an inhibitor of this kinase was efficient against CLL [172]. Thus activating these pathways by molecules less toxic than phorbolmyristate acetate might prove useful to down regulate CXCR4, alternatively, pharmacological inhibitors of regulators, such as phosphatases of the PKC pathway might be useful as well.

In Waldenstom's Macroglobulinemia (WM), macroglobulinemia designs an increase in serum concentrations of $\operatorname{IgM}$ and causes much of the morbidity associated with the disease. WM is an indolent B-cell malignancy with a monoclonal proliferation of IgM-producing PCs that fail to undergo Ig isotype switching. WM is uncommon relative to plasma cells (PC) myeloma [173]. Although the pathogenesis of WM remained undetermined several data suggested that genetic factors contributed to the disease [174]. PCs from WM are CXCR4 ${ }^{\text {hiVLAA }} 4^{\text {hi }}$ and as for normal PC, malignant PC continuously home into the bone marrow and trans endothelial migration of PC from WM depends on CXCL12/CXCR4 [175]. It is now clear that WM results from somatic mutations in PC precursors.

A recent study evidenced somaticCXCR4 mutation in $28 \%$ of the patients PC [16]. Five distinct somatic mutations were located in the CXCR4 C-terminal tail, each of which were identical or functionally similar to mutations associated with WHIM syndrome (WS), resulting in the loss of regulatory Ser/Thr residues likely leading to impaired inactivation. CXCR4 is the second most frequent somatic mutation in WM next to L265P-MYD88 mutation that was detected in $90 \%$ of cases. Most interestingly, $98 \%$ of patients with CXCR4 mutation harboured the MYD88 mutation. These results imply that a gain of function CXCR4 is involved in the pathogeny of WM. It remains to understand how this helps malignant transformation to occur, and how to reconcile this observation with hypogammaglobulinemia in the WS. An interesting perspective here is the potential useful treatment of WM patients mutated or not for CXCR4, with AMD3100. It will undoubtedly represent the second therapeutic indication of plerixafor after WS.

\section{CXCR4 and solid tumours}

CXCR4 plays a critical role in the promotion of several solid tumours. A recent study showed that non-small lung cancer cell lines did express high CXCR4 despite secreting CXCL12 [176]; this questions the inability of CXCL12 to down regulate CXCR4 in these cells. Moreover these cells had a high self-renewal and tumour promoting activity in vivo. Thus CXCR4 may behave as a growth stimulator and help cancer stem cells home into protective niches within the solid tumour or metastasize within the bone marrow where they may compete with normal HSC, hence adverse effects on immunity and haematopoiesis.

A common feature of WS and ICL is the occurrence of cancers that are often linked to HPV infections. In ICL, some 15\% of the patients experienced HPV infections and / or squamous and basal cell carcinomas of the skin, Bowen's disease, vulvar, cervical or bladder carcinomas [122]. Interestingly, HPV has been detected in these pathologies [177-181]. In WS, clinical manifestations at diagnosis include cervical papillomatosis that can lead to invasive cancer [112]. This highlights the potential and still undetermined role of CXCR4 (over or impaired 
membrane expression) in the control of immunity to HPV. It also points to the fact that the term "gain of function" for the CXCR $4{ }^{1013}$ mutation may be a misnomer as it points for an augmented capacity of the cells to migrate in vitro and most likely to stick to their niches in vivo. Of note, there is no correlation between HPV-associated cancers and Waldenstom's Macroglobulinemia, which only affects PC and leaves intact most immune cells with normal CXCR4. The germ line CXCR4 $4^{1013}$-mutation is clearly associated with a polyclonal loss of function of B-, T-and NK-cells in vivo and possibly of neutrophils as well and the respective contribution of these leukocytes to the adaptive immune response against HPV remains to be understood.

Within solid tumours or among malignant cells from leukaemia's, several lines of evidence suggest that there are cells called cancer stem cells or tumour initiating cells. They have been identified in many types of cancers including human gastric tumour, mammary gland, brain, prostate gland, colon pancreas, head and neck and liver [182-190]. On primary cultures of cells from a human gastric tumour, those cells are able to grow on extracellular matrix and to form spheroid, structures specific of stem cells. Furthermore those cells are more resistant to chemotherapy and capable of self-renewal [182]. This feature could explain the failure in the treatment of cancers. In a Gefitinib-resistant non-small cell lung cancer cells line (A549/GR), experiments show that these cells possess some features of stem cells such as the acquisition of epithelial mesenchymal transition property. More interestingly, there is a high proportion of CXCR4 ${ }^{+}$cells in A549/GR, with high self-renewal activity in vitro, high tumorigenic potential in vivo, a strong sphere-forming activity and a resistance to radiation. The use of si-RNA specific of CXCR4 or the AMD3100 are both able to suppressed sphere forming activity in those cell lines, demonstrating an important role of CXCR4 in maintaining cancer stem cells features in A549/GR [176]. Cancer stem cells are potential targets for therapies in order to eliminate malignant cells in solid tumours resistant to chemotherapy.

The CXCL12/CXCR4 axis is known to be involved in tumour growth and metastatic process. The microenvironment is essential for tumour development and stromal and malignant cells communicate via growth factors and cytokines [191, 192]. In order to understand the impact of Cxcr4 in the microenvironment on metastasis of tumour cells, D'Alterio et al injected murine melanoma B16 cells on C57BL/6 Cxcr $4^{+++}$or Cxcr4 $4^{+/}$mice in the presence of AMD3100. In Cxcr4 $4^{+-}$ mice nodule size were significantly smaller and bone marrow-derived cells recruitment was lower compared to $\mathrm{C} x \mathrm{Cr} 4^{+/+}$. Furthermore, the Cxcr4 inhibitor AMD3100 preserves the pulmonary architecture in $\mathrm{Cxcr}^{+/-}$mice by reducing lung metastases. $\mathrm{C} x \mathrm{cr} 4^{+/}$-mice also show a decrease in LY6G-positive myeloid/granulocytic cells and in p38 MAPK activation in lungs compared to $\mathrm{Cxcr}^{+/+}$mice [193]. These experiments demonstrate the importance CXCL12/ CXCR4 axis in the microenvironment regarding metastases and tumour growth. Since CXCL12/CXCR4 axis may promote cancer cell survival, invasion, and tumour-initiating cell phenotype. Therefore blocking this axis may be a potential approach to target various components in solid tumours.

The CXCL12/CXCR4 axis is also involved in the recruitment of immune cells into the tumour as described for regulatory T-cells (Tregs). Indeed Tregs expressing CXCR4 are recruited in a number of tumours including ovarian cancer, adenocarcinoma of the lung, malignant meso- 
thelioma and the myelodysplastic syndromes [194-197]. In cancer, the balance between Tregsand T-effector cells is often deregulated and Tregs are recruited to the tumour, a process that suppress the anti-tumour immune response leading to tumour growth. In basal-like breast cancer, it was shown that there is a positive correlation between CXCL12 expression in the tumour and Tregs recruitment correlated with a poor survival in patients [198]. This was also shown in lung adenocarcinomas and malignant mesothelioma [195, 196]. In addition Yan et al showed that the recruitment of Tregs is correlated with hypoxia-induced CXCR4 expression in basal-like breast cancers. Furthermore, in lung adenocarcinoma, CXCR4 positive Tregs cells are able to regulate the immune response and to secrete tumour growth factor- $\beta$ which upregulate CXCR4 on naive T-cells and contribute to their migration and retention in the tumour microenvironment and that contribute to increase pathogenesis [195]. Overall, these observations suggest that CXCL12 expression may influence tumour progression by shaping the immune cell population infiltrating lung adenocarcinoma tumours. In human ovarian carcinoma, Tregs preferentially move to tumours and ascites and suppress tumour-specific Tcell immunity and contribute to growth of human tumours in vivo. The recruitment of Tregs represents a mechanism by which tumours may promote immune advantage. Altogether, these results suggest that AMD3100 or other drugs that target the CXCL12/CXCR4 axis may be useful adjuncts for immune-chemotherapy in some cancers [199].

\section{Conclusion/therapeutic perspectives}

The contribution of the CXCL12/CXCR4 signaling axis to many aspects of physiology and pathology has been increasingly appreciated (Figure $1 \& 2$ ). Deregulations of CXCR4 signaling and/or expression are associated with several disorders including lymphoid and autoimmune diseases, solid tumours and immune defects [15, 200-203]. Therefore, interference with the CXCL12/CXCR4 interaction or modulation of CXCR4 expression and/or activity is potentially interesting in the treatment of diseases with loss or gain of function of CXCR4. In this context and for the last two decades, many pharmaceutical companies have been trying to develop specific drugs targeting this axis [204, 205]. In light of recent clinical investigations, the bicyclamplerixafor (AMD3100), has already been approved by the FDA for HSC mobilization in patients with non-Hodgkin's lymphoma and multiple myeloma [206]. In addition, Plerixafor is already under Phase I of clinical investigation in Glioma, Acute Myeloid leukaemia, CLL and WS [204, 207]. Furthermore, regarding the low half-life, the constraining frequency of administration of AMD3100, several promising CXCR4 antagonists have been developed to block CXCL12/CXCR4 interactions that are currently under different stages of clinical trials mainly for HSC transplantation in patients with multiple myeloma and non-Hodgkin's lymphoma [205]. Most of them neutralize the interaction of CXCL12 with CXCR4 by binding to the receptor. Another way is to directly target CXCL12 by developing molecules that interact directly with it thus diverting the chemokine from its receptor. For example blocking interactions of CXCL12 with the extracellular matrix and cell surface glycosaminoglycans may be an approach by developing CXCL12 binding heparansulphates. In addition other strategies will be to generate molecules interfering with intracellular trafficking and expression of CXCR4 
which are two different ways to normalize CXCR4 expression and functioning in pathologies associated with CXCR4 anomalies as seen both in ICL and WS. As mentioned in the introduction, ACKR3 may share overlapping functions with CXCR4 and is possibly involved in the same pathologies and need to be investigated in this respect [208, 209].

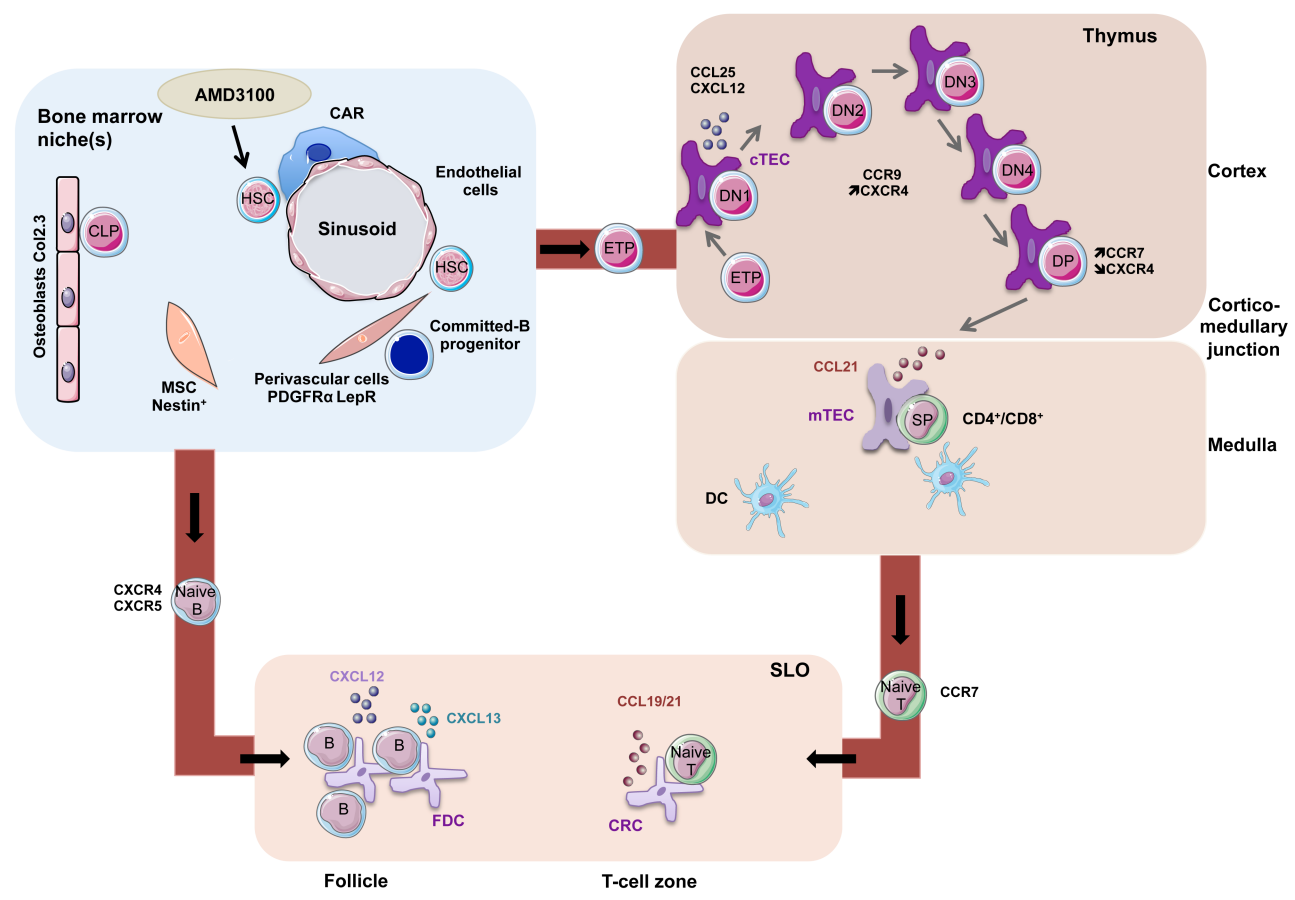

Figure 1. CXCR4 in lymphopoiesis. Most primitive hematopoietic stem cells (HSC) and downstream lymphoid progenitors, including common lymphoid (CLP) and committed B-cell precursors express CXCR4 and the differentiation of HSC and B-cell precursors is CXCR4-dependent. These cells interact with CXCL12-expressing stromal cells. These stromal cells comprise Nestin+Mesenchymal stem cells MSC, CXCL12-producing reticular cells (CAR), perivascular cells expressing PDGFR and LeptinR, and osteoblasts. AMD3100 is already used to allow the migration of HSC in the peripheral blood of patients in order to be collected for grafting. Recent data suggest that B-cell progenitors locate near the perivascular niche. CLP locate in the osteoblastic niche. Downstream progenitors migrate through the blood and enter the thymus at the cortico-medullary junction where they constitute early thymic progenitors (ETP). ETP further move inside the cortex and differentiate in several double negative CD4-CD8 stages DN1 to DN4. This process depends on the production of CXCL12 by cortical thymic epithelial cells (CTEC). At the DN4 stage, thymocytes downregulate CXCR4, upregulate CCR7 and become $C D 4^{+} C D 8^{+}\left(C D 3^{+}\right)$cells double positive DP cells. DP thymocytes are attracted by CCL21-producing thymic medullary epithelial cells (MTEC). At the end of differentiation, and negative selection due to interactions with dendritic cells (DC) in the medulla, naive single positive (SP) CD4+or CD8+thymocytes egress from the thymus to the bloodstream and further migrate to the T-cell zones of secondary lymphoid organs (SLO). In parallel B-cell precursors differentiate within the bone marrow in naive B-cells that express CXCR4/5 and migrate to the SLO, where they organize themselves around CXCL12/13-producing follicular dendritic cells (FDC) and marginal central reticular cells (CRC). Following T-dependent response to antigen the germinal centre (GC)reaction is initiated (figure 2). 


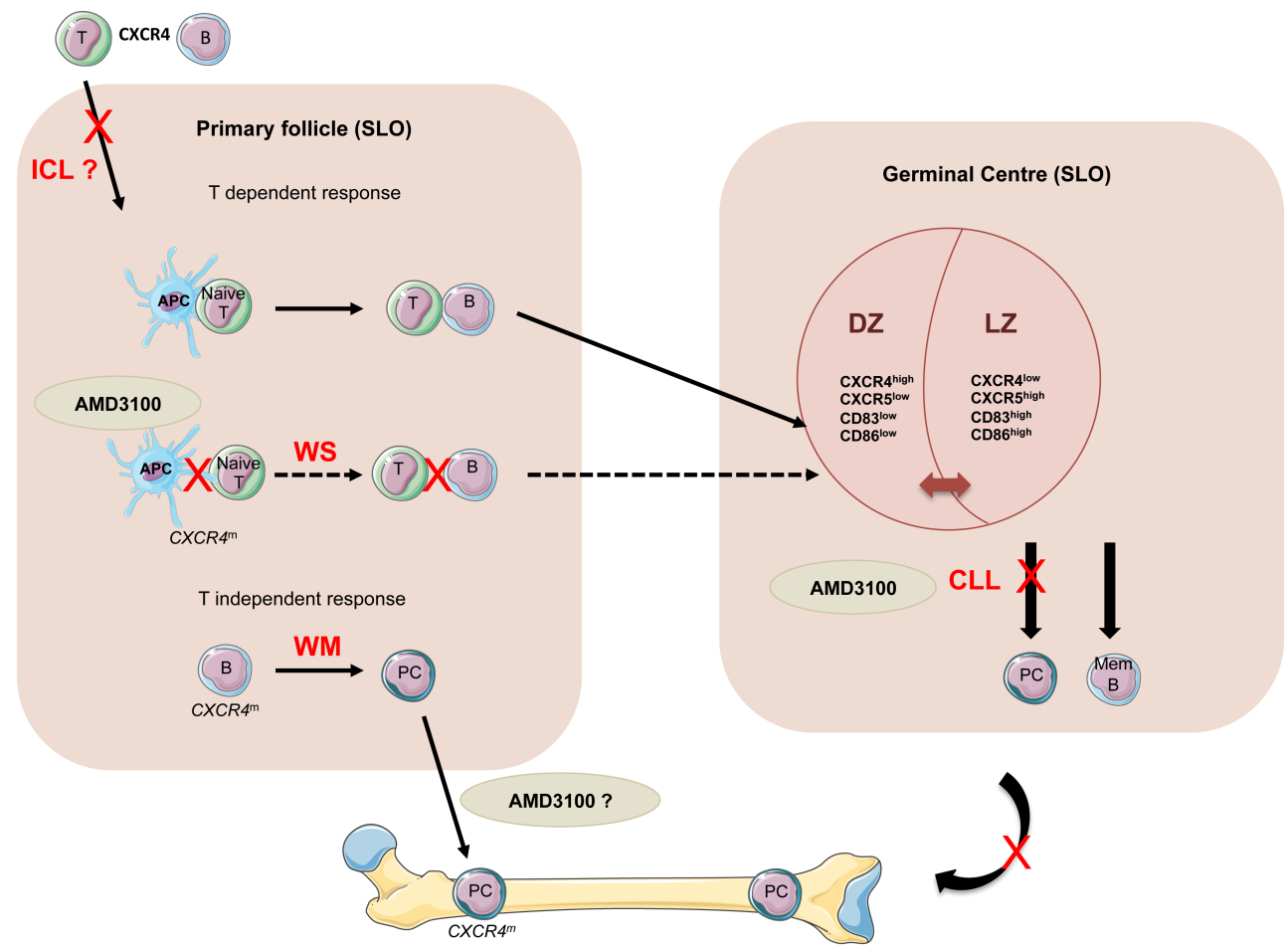

Figure 2. CXCR4 in T-dependent antigen response, and in pathology. Following antigen capture and processing, dendritic antigen-presenting cells (APC) move to the T-cell zone in the SLO to prime antigen-specific T-cells whereas follicular B-cells are stimulated by soluble antigen. In turn T-and B-cells move towards each other and antigen-specific B-cells expand to generate the dark zone DZ made mostly of centroblasts. These cells differentiate in centrocytes that constitute the light zone and downregulate CXCR4. Ultimately, centrocytes differentiate in memory B-cells or plasma cells (PC), the laterupregulate CXCR4 and migrate to the bone marrow. In the WS, one hypothesis is that the germline $C X C R 4^{m}$ mutation impairs T-APC and T-B interactions leading to deficient GC formation. In Waldenstom's MacroglobulinemiaWM, the somatic $C X C R 4^{m}$ mutation in B-cells confers a survival advantage and drives PC to migrate and home into the bone marrow were they become malignant due to additional gain of function mutations such as in the MYD88 gene. In the Idiopathic CD4+T-cell LymphocytopenialCL, downregulation of CXCR4 expression in T-cells may concur to the deficient adaptive immune response. In chronic lymphocytic leukaemia, PC differentiation is impaired and leukemic B-cells express CXCR4, which keeps them in a protective environment in contact with CXCL12-producing stromal cells thereby protecting them from immune/chemotherapeutic drugs. In this context, AMD3100 plerixafor may help sensitize chronic lymphocytic leukaemia CLL cells to drugs. Plerixafor is already used for the treatment of WHIM Syndrome WS, and may prove useful in the treatment of WM.

A new therapeutic era has begun, next years will witness the use of anti-chemokines receptors to prevent malignant cells from interacting with their protective stromal cells and of inflammatory cells to migrate into tissues, these new families of drugs should clearly improve the efficacy of current anti-cancer, anti-autoimmune and anti-inflammatory molecules [182]. 


\section{Acknowledgements}

This work was supported by the Assistance Publique-Hôpitaux de Paris (Grant 07018) and the Agence Nationale de la Recherche (Grant 2010 JCJC 1104 01). C.F., A.B., K.B., and A.D. are membres of the Laboratory of Excellence in Research on Medication and Innovative Therapeutics, supported by a grant from the Agence Nationale de la Recherche (ANR-10-LABX-33) under the program "Investissements d'Avenir" ANR-11-IDEX-0003-01. A.B., C.F. are fellowship recipients from the Fondation pour la Recherche Médicale (FDT20130928127), the French Ministry and the DIM Biothérapies, respectively.

Figures were adapted from Servier Medical Art http://smart.servier.fr/servier-medicalartunder licence Creative Commons Attribution 3.0 France http://creativecommons.org/ licenses/by/3.0/fr/.

\section{Author details}

Christelle Freitas $^{1,2}$, Alexandre Bignon ${ }^{1,2}$, Karl Balabanian $^{1,2}$ and Ali Dalloul ${ }^{1,2^{*}}$

*Address all correspondence to: ali.dalloul@u-psud.fr

1 Université Paris-Sud, Laboratoire “Cytokines, Chimiokines et Immunopathologie," Clamart, France

2 INSERM, Laboratoire d'Excellence en Recherche sur le Médicament et l'Innovation Thérapeutique, Clamart, France

Christelle Freitas and Alexandre Bignon contributed equally to this work.

\section{References}

[1] Nagasawa T, Kikutani H, Kishimoto T. Molecular cloning and structure of a pre-Bcell growth-stimulating factor. Proc Natl Acad Sci U S A. 1994 Mar 15;91 (6):2305-9.

[2] Oberlin E, Amara A, Bachelerie F, Bessia C, Virelizier JL, Arenzana-Seisdedos F, et al. The CXC chemokine SDF-1 is the ligand for LESTR/fusin and prevents infection by T-cell-line-adapted HIV-1. Nature. 1996 Aug 29;382 (6594):833-5.

[3] Berger EA, Murphy PM, Farber JM. Chemokine receptors as HIV-1 coreceptors: roles in viral entry, tropism, and disease. Annu Rev Immunol. 1999;17:657-700.

[4] Katsumoto K, Kume S. Endoderm and mesoderm reciprocal signaling mediated by CXCL12 and CXCR4 regulates the migration of angioblasts and establishes the pancreatic fate. Development. 2011 May;138 (10):1947-55. 
[5] Nair S, Schilling TF. Chemokine signaling controls endodermal migration during zebrafish gastrulation. Science. 2008 Oct 3;322 (5898):89-92.

[6] Ceradini DJ, Kulkarni AR, Callaghan MJ, Tepper OM, Bastidas N, Kleinman ME, et al. Progenitor cell trafficking is regulated by hypoxic gradients through HIF-1 induction of SDF-1. Nat Med. 2004 Aug;10 (8):858-64.

[7] Mohyeldin A, Garzon-Muvdi T, Quinones-Hinojosa A. Oxygen in stem cell biology: a critical component of the stem cell niche. Cell Stem Cell. 2010 Aug 6;7 (2):150-61.

[8] Nagasawa T, Hirota S, Tachibana K, Takakura N, Nishikawa S, Kitamura Y, et al. Defects of B-cell lymphopoiesis and bone-marrow myelopoiesis in mice lacking the CXC chemokine PBSF/SDF-1. Nature. 1996 Aug 15;382 (6592):635-8.

[9] Law NM, Rosenzweig SA. Characterization of the G-protein linked orphan receptor GPRN1/RDC1. Biochem Biophys Res Commun. 1994 May 30;201 (1):458-65.

[10] Balabanian K, Lagane B, Infantino S, Chow KY, Harriague J, Moepps B, et al. The chemokine SDF-1/CXCL12 binds to and signals through the orphan receptor RDC1 in T lymphocytes. J Biol Chem. 2005 Oct 21;280 (42):35760-6.

[11] Burns JM, Summers BC, Wang Y, Melikian A, Berahovich R, Miao Z, et al. A novel chemokine receptor for SDF-1 and I-TAC involved in cell survival, cell adhesion, and tumor development. J Exp Med. 2006 Sep 4;203 (9):2201-13.

[12] Marchese A, Benovic JL. Agonist-promoted ubiquitination of the G protein-coupled receptor CXCR4 mediates lysosomal sorting. J Biol Chem. 2001 Dec 7;276 (49): 45509-12.

[13] Marchese A, Raiborg C, Santini F, Keen JH, Stenmark H, Benovic JL. The E3 ubiquitin ligase AIP4 mediates ubiquitination and sorting of the $G$ protein-coupled receptor CXCR4. Dev Cell. 2003 Nov;5 (5):709-22.

[14] Busillo JM, Benovic JL. Regulation of CXCR4 signaling. Biochim Biophys Acta. 2007 Apr;1768 (4):952-63.

[15] Bignon A, Biajoux V, Bouchet-Delbos L, Emilie D, Lortholary O, Balabanian K. [CXCR4, a therapeutic target in rare immunodeficiencies?]. Med Sci (Paris). 2011 Apr;27 (4):391-7.

[16] Hunter Z, Xu L, Yang G, Zhou Y, Liu X, Cao Y, et al. The genomic landscape of Waldenstom's Macroglobulinemia is characterized by highly recurring MYD88 and WHIM-like CXCR4 mutations, and small somatic deletions associated with B-cell lymphomagenesis. Blood. 2013 Dec 23.

[17] Van Damme J, Struyf S, Wuyts A, Van Coillie E, Menten P, Schols D, et al. The role of CD26/DPP IV in chemokine processing. Chem Immunol. 1999;72:42-56.

[18] Fermas S, Gonnet F, Sutton A, Charnaux N, Mulloy B, Du Y, et al. Sulfated oligosaccharides (heparin and fucoidan) binding and dimerization of stromal cell-derived 
factor-1 (SDF-1/CXCL 12) are coupled as evidenced by affinity CE-MS analysis. Glycobiology. 2008 Dec;18 (12):1054-64.

[19] Peacock JW, Jirik FR. TCR activation inhibits chemotaxis toward stromal cell-derived factor-1: evidence for reciprocal regulation between CXCR4 and the TCR. J Immunol. 1999 Jan 1;162 (1):215-23.

[20] Guinamard R, Signoret N, Ishiai M, Marsh M, Kurosaki T, Ravetch JV. B cell antigen receptor engagement inhibits stromal cell-derived factor (SDF)-1alpha chemotaxis and promotes protein kinase C (PKC)-induced internalization of CXCR4. J Exp Med. 1999 May 3;189 (9):1461-6.

[21] Este JA, Cabrera C, De Clercq E, Struyf S, Van Damme J, Bridger G, et al. Activity of different bicyclam derivatives against human immunodeficiency virus depends on their interaction with the CXCR4 chemokine receptor. Mol Pharmacol. 1999 Jan;55 (1):67-73.

[22] Arroyo AG, Yang JT, Rayburn H, Hynes RO. Alpha4 integrins regulate the proliferation/differentiation balance of multilineage hematopoietic progenitors in vivo. Immunity. 1999 Nov;11 (5):555-66.

[23] Sugiyama T, Kohara H, Noda M, Nagasawa T. Maintenance of the hematopoietic stem cell pool by CXCL12-CXCR4 chemokine signaling in bone marrow stromal cell niches. Immunity. 2006 Dec;25 (6):977-88.

[24] Frenette PS, Subbarao S, Mazo IB, von Andrian UH, Wagner DD. Endothelial selectins and vascular cell adhesion molecule-1 promote hematopoietic progenitor homing to bone marrow. Proc Natl Acad Sci U S A. 1998 Nov 24;95 (24):14423-8.

[25] Spertini O, Cordey AS, Monai N, Giuffre L, Schapira M. P-selectin glycoprotein ligand 1 is a ligand for L-selectin on neutrophils, monocytes, and CD34+hematopoietic progenitor cells. J Cell Biol. 1996 Oct;135 (2):523-31.

[26] Oostendorp RA, Dormer P. VLA-4-mediated interactions between normal human hematopoietic progenitors and stromal cells. Leuk Lymphoma. 1997 Feb;24 (5-6): 423-35.

[27] Peled A, Grabovsky V, Habler L, Sandbank J, Arenzana-Seisdedos F, Petit I, et al. The chemokine SDF-1 stimulates integrin-mediated arrest of CD34 (+) cells on vascular endothelium under shear flow. J Clin Invest. 1999 Nov;104 (9):1199-211.

[28] Naiyer AJ, Jo DY, Ahn J, Mohle R, Peichev M, Lam G, et al. Stromal derived factor-1induced chemokinesis of cord blood CD34 (+) cells (long-term culture-initiating cells) through endothelial cells is mediated by E-selectin. Blood. 1999 Dec 15;94 (12):4011-9.

[29] Fuste B, Escolar G, Marin P, Mazzara R, Ordinas A, Diaz-Ricart M. G-CSF increases the expression of VCAM-1 on stromal cells promoting the adhesion of CD34+hematopoietic cells: studies under flow conditions. Exp Hematol. 2004 Aug;32 (8):765-72. 
[30] Jo DY, Rafii S, Hamada T, Moore MA. Chemotaxis of primitive hematopoietic cells in response to stromal cell-derived factor-1. J Clin Invest. 2000 Jan;105 (1):101-11.

[31] Peled A, Petit I, Kollet O, Magid M, Ponomaryov T, Byk T, et al. Dependence of human stem cell engraftment and repopulation of NOD/SCID mice on CXCR4. Science. 1999 Feb 5;283 (5403):845-8.

[32] Aiuti A, Webb IJ, Bleul C, Springer T, Gutierrez-Ramos JC. The chemokine SDF-1 is a chemoattractant for human CD34+hematopoietic progenitor cells and provides a new mechanism to explain the mobilization of CD34+progenitors to peripheral blood. J Exp Med. 1997 Jan 6;185 (1):111-20.

[33] Nie Y, Han YC, Zou YR. CXCR4 is required for the quiescence of primitive hematopoietic cells. J Exp Med. 2008 Apr 14;205 (4):777-83.

[34] Eaves CJ. SDF-1 tells stem cells to mind their P's and Z's. J Clin Invest. 2005 Jan;115 (1):27-9.

[35] Lataillade JJ, Clay D, Dupuy C, Rigal S, Jasmin C, Bourin P, et al. Chemokine SDF-1 enhances circulating CD34 (+) cell proliferation in synergy with cytokines: possible role in progenitor survival. Blood. 2000 Feb 1;95 (3):756-68.

[36] Lataillade JJ, Clay D, Bourin P, Herodin F, Dupuy C, Jasmin C, et al. Stromal cell-derived factor 1 regulates primitive hematopoiesis by suppressing apoptosis and by promoting G (0)/G (1) transition in CD34 (+) cells: evidence for an autocrine/paracrine mechanism. Blood. 2002 Feb 15;99 (4):1117-29.

[37] Ding L, Morrison SJ. Haematopoietic stem cells and early lymphoid progenitors occupy distinct bone marrow niches. Nature. 2013 Mar 14;495 (7440):231-5.

[38] Kiel MJ, Yilmaz OH, Iwashita T, Terhorst C, Morrison SJ. SLAM family receptors distinguish hematopoietic stem and progenitor cells and reveal endothelial niches for stem cells. Cell. 2005 Jul 1;121 (7):1109-21.

[39] Mendez-Ferrer S, Michurina TV, Ferraro F, Mazloom AR, Macarthur BD, Lira SA, et al. Mesenchymal and haematopoietic stem cells form a unique bone marrow niche. Nature. 2010 Aug 12;466 (7308):829-34.

[40] Ding L, Saunders TL, Enikolopov G, Morrison SJ. Endothelial and perivascular cells maintain haematopoietic stem cells. Nature. 2012 Jan 26;481 (7382):457-62.

[41] Greenbaum A, Hsu YM, Day RB, Schuettpelz LG, Christopher MJ, Borgerding JN, et al. CXCL12 in early mesenchymal progenitors is required for haematopoietic stemcell maintenance. Nature. 2013 Mar 14;495 (7440):227-30.

[42] Donzella GA, Schols D, Lin SW, Este JA, Nagashima KA, Maddon PJ, et al. AMD3100, a small molecule inhibitor of HIV-1 entry via the CXCR4 co-receptor. Nat Med. 1998 Jan;4 (1):72-7. 
[43] Mosi RM, Anastassova V, Cox J, Darkes MC, Idzan SR, Labrecque J, et al. The molecular pharmacology of AMD11070: an orally bioavailable CXCR4 HIV entry inhibitor. Biochem Pharmacol. 2012 Feb 15;83 (4):472-9.

[44] Pusic I, DiPersio JF. Update on clinical experience with AMD3100, an SDF-1/ CXCL12-CXCR4 inhibitor, in mobilization of hematopoietic stem and progenitor cells. Curr Opin Hematol. 2010 Jul;17 (4):319-26.

[45] Publicover A, Richardson DS, Davies A, Hill KS, Hurlock C, Hutchins D, et al. Use of a biosimilar granulocyte colony-stimulating factor for peripheral blood stem cell mobilization: an analysis of mobilization and engraftment. Br J Haematol. 2013 Jul;162 (1):107-11.

[46] Petit I, Szyper-Kravitz M, Nagler A, Lahav M, Peled A, Habler L, et al. G-CSF induces stem cell mobilization by decreasing bone marrow SDF-1 and up-regulating CXCR4. Nat Immunol. 2002 Jul;3 (7):687-94.

[47] Lambeir AM, Proost P, Durinx C, Bal G, Senten K, Augustyns K, et al. Kinetic investigation of chemokine truncation by CD26/dipeptidyl peptidase IV reveals a striking selectivity within the chemokine family. J Biol Chem. 2001 Aug 10;276 (32):29839-45.

[48] Zou YR, Kottmann AH, Kuroda M, Taniuchi I, Littman DR. Function of the chemokine receptor CXCR4 in haematopoiesis and in cerebellar development. Nature. 1998 Jun 11;393 (6685):595-9.

[49] Ma Q, Jones D, Springer TA. The chemokine receptor CXCR4 is required for the retention of B lineage and granulocytic precursors within the bone marrow microenvironment. Immunity. 1999 Apr;10 (4):463-71.

[50] D'Apuzzo M, Rolink A, Loetscher M, Hoxie JA, Clark-Lewis I, Melchers F, et al. The chemokine SDF-1, stromal cell-derived factor 1, attracts early stage B cell precursors via the chemokine receptor CXCR4. Eur J Immunol. 1997 Jul;27 (7):1788-93.

[51] Kawabata K, Ujikawa M, Egawa T, Kawamoto H, Tachibana K, lizasa H, et al. A cellautonomous requirement for CXCR4 in long-term lymphoid and myeloid reconstitution. Proc Natl Acad Sci U S A. 1999 May 11;96 (10):5663-7.

[52] Dittel BN, McCarthy JB, Wayner EA, LeBien TW. Regulation of human B-cell precursor adhesion to bone marrow stromal cells by cytokines that exert opposing effects on the expression of vascular cell adhesion molecule-1 (VCAM-1). Blood. 1993 May $1 ; 81$ (9):2272-82.

[53] Glodek AM, Honczarenko M, Le Y, Campbell JJ, Silberstein LE. Sustained activation of cell adhesion is a differentially regulated process in B lymphopoiesis. J Exp Med. 2003 Feb 17;197 (4):461-73.

[54] Nagasawa T. The chemokine CXCL12 and regulation of HSC and B lymphocyte development in the bone marrow niche. Adv Exp Med Biol. 2007;602:69-75. 
[55] Zhu J, Garrett R, Jung Y, Zhang Y, Kim N, Wang J, et al. Osteoblasts support B-lymphocyte commitment and differentiation from hematopoietic stem cells. Blood. 2007 May 1;109 (9):3706-12.

[56] Wu JY, Purton LE, Rodda SJ, Chen M, Weinstein LS, McMahon AP, et al. Osteoblastic regulation of B lymphopoiesis is mediated by Gs\{alpha\}-dependent signaling pathways. Proc Natl Acad Sci U S A. 2008 Nov 4;105 (44):16976-81.

[57] Honczarenko M, Douglas RS, Mathias C, Lee B, Ratajczak MZ, Silberstein LE. SDF-1 responsiveness does not correlate with CXCR4 expression levels of developing human bone marrow B cells. Blood. 1999 Nov 1;94 (9):2990-8.

[58] Honczarenko M, Le Y, Glodek AM, Majka M, Campbell JJ, Ratajczak MZ, et al. CCR5-binding chemokines modulate CXCL12 (SDF-1)-induced responses of progenitor $\mathrm{B}$ cells in human bone marrow through heterologous desensitization of the CXCR4 chemokine receptor. Blood. 2002 Oct 1;100 (7):2321-9.

[59] Balabanian K, Brotin E, Biajoux V, Bouchet-Delbos L, Lainey E, Fenneteau O, et al. Proper desensitization of CXCR4 is required for lymphocyte development and peripheral compartmentalization in mice. Blood. 2012 Jun 14;119 (24):5722-30.

[60] Cyster JG. B cell follicles and antigen encounters of the third kind. Nat Immunol. 2010 Nov;11 (11):989-96.

[61] Pereira JP, Kelly LM, Cyster JG. Finding the right niche: B-cell migration in the early phases of T-dependent antibody responses. Int Immunol. 2010 Jun;22 (6):413-9.

[62] Okada T, Ngo VN, Ekland EH, Forster R, Lipp M, Littman DR, et al. Chemokine requirements for B cell entry to lymph nodes and Peyer's patches. J Exp Med. 2002 Jul 1;196 (1):65-75.

[63] Revy P, Muto T, Levy Y, Geissmann F, Plebani A, Sanal O, et al. Activation-induced cytidine deaminase (AID) deficiency causes the autosomal recessive form of the Hyper-IgM syndrome (HIGM2). Cell. 2000 Sep 1;102 (5):565-75.

[64] Neuberger MS, Milstein C. Somatic hypermutation. Curr Opin Immunol. 1995 Apr;7 (2):248-54.

[65] Victora GD, Dominguez-Sola D, Holmes AB, Deroubaix S, Dalla-Favera R, Nussenzweig MC. Identification of human germinal center light and dark zone cells and their relationship to human B-cell lymphomas. Blood. 2012 Sep 13;120 (11):2240-8.

[66] Hennino A, Berard M, Krammer PH, Defrance T. FLICE-inhibitory protein is a key regulator of germinal center B cell apoptosis. J Exp Med. 2001 Feb 19;193 (4):447-58.

[67] Allen CD, Ansel KM, Low C, Lesley R, Tamamura H, Fujii N, et al. Germinal center dark and light zone organization is mediated by CXCR4 and CXCR5. Nat Immunol. 2004 Sep;5 (9):943-52. 
[68] Kabashima K, Haynes NM, Xu Y, Nutt SL, Allende ML, Proia RL, et al. Plasma cell S1P1 expression determines secondary lymphoid organ retention versus bone marrow tropism. J Exp Med. 2006 Nov 27;203 (12):2683-90.

[69] Nie Y, Waite J, Brewer F, Sunshine MJ, Littman DR, Zou YR. The role of CXCR4 in maintaining peripheral B cell compartments and humoral immunity. J Exp Med. 2004 Nov 1;200 (9):1145-56.

[70] Slifka MK, Antia R, Whitmire JK, Ahmed R. Humoral immunity due to long-lived plasma cells. Immunity. 1998 Mar;8 (3):363-72.

[71] Koni PA, Joshi SK, Temann UA, Olson D, Burkly L, Flavell RA. Conditional vascular cell adhesion molecule 1 deletion in mice: impaired lymphocyte migration to bone marrow. J Exp Med. 2001 Mar 19;193 (6):741-54.

[72] Signoret N, Oldridge J, Pelchen-Matthews A, Klasse PJ, Tran T, Brass LF, et al. Phorbol esters and SDF-1 induce rapid endocytosis and down modulation of the chemokine receptor CXCR4. J Cell Biol. 1997 Nov 3;139 (3):651-64.

[73] Haribabu B, Richardson RM, Fisher I, Sozzani S, Peiper SC, Horuk R, et al. Regulation of human chemokine receptors CXCR4. Role of phosphorylation in desensitization and internalization. J Biol Chem. 1997 Nov 7;272 (45):28726-31.

[74] Bleul CC, Schultze JL, Springer TA. B lymphocyte chemotaxis regulated in association with microanatomic localization, differentiation state, and B cell receptor engagement. J Exp Med. 1998 Mar 2;187 (5):753-62.

[75] Godfrey DI, Zlotnik A. Control points in early T-cell development. Immunol Today. 1993 Nov;14 (11):547-53.

[76] Inlay MA, Bhattacharya D, Sahoo D, Serwold T, Seita J, Karsunky H, et al. Ly6d marks the earliest stage of B-cell specification and identifies the branchpoint between B-cell and T-cell development. Genes Dev. 2009 Oct 15;23 (20):2376-81.

[77] Petrie HT, Zuniga-Pflucker JC. Zoned out: functional mapping of stromal signaling microenvironments in the thymus. Annu Rev Immunol. 2007;25:649-79.

[78] Dalloul AH, Patry C, Salamero J, Canque B, Grassi F, Schmitt C. Functional and phenotypic analysis of thymic CD34+CD1a-progenitor-derived dendritic cells: predominance of CD1a+differentiation pathway. J Immunol. 1999 May 15;162 (10):5821-8.

[79] Blom B, Spits H. Development of human lymphoid cells. Annu Rev Immunol. 2006;24:287-320.

[80] Shortman K, Egerton M, Spangrude GJ, Scollay R. The generation and fate of thymocytes. Semin Immunol. 1990 Jan;2 (1):3-12.

[81] Ehrlich LI, Oh DY, Weissman IL, Lewis RS. Differential contribution of chemotaxis and substrate restriction to segregation of immature and mature thymocytes. Immunity. 2009 Dec 18;31 (6):986-98. 
[82] Plotkin J, Prockop SE, Lepique A, Petrie HT. Critical role for CXCR4 signaling in progenitor localization and $\mathrm{T}$ cell differentiation in the postnatal thymus. J Immunol. 2003 Nov 1;171 (9):4521-7.

[83] Griffith AV, Fallahi M, Nakase H, Gosink M, Young B, Petrie HT. Spatial mapping of thymic stromal microenvironments reveals unique features influencing $\mathrm{T}$ lymphoid differentiation. Immunity. 2009 Dec 18;31 (6):999-1009.

[84] Love PE, Bhandoola A. Signal integration and crosstalk during thymocyte migration and emigration. Nat Rev Immunol. 2011 Jul;11 (7):469-77.

[85] Halkias J, Melichar HJ, Taylor KT, Ross JO, Yen B, Cooper SB, et al. Opposing chemokine gradients control human thymocyte migration in situ. J Clin Invest. 2013 May $1 ; 123$ (5):2131-42.

[86] Trampont PC, Tosello-Trampont AC, Shen Y, Duley AK, Sutherland AE, Bender TP, et al. CXCR4 acts as a costimulator during thymic beta-selection. Nat Immunol. 2010 Feb;11 (2):162-70.

[87] Janas ML, Varano G, Gudmundsson K, Noda M, Nagasawa T, Turner M. Thymic development beyond beta-selection requires phosphatidylinositol 3-kinase activation by CXCR4. J Exp Med. 2010 Jan 18;207 (1):247-61.

[88] Nakano H, Mori S, Yonekawa H, Nariuchi H, Matsuzawa A, Kakiuchi T. A novel mutant gene involved in T-lymphocyte-specific homing into peripheral lymphoid organs on mouse chromosome 4. Blood. 1998 Apr 15;91 (8):2886-95.

[89] Pui JC, Allman D, Xu L, DeRocco S, Karnell FG, Bakkour S, et al. Notch1 expression in early lymphopoiesis influences B versus T lineage determination. Immunity. 1999 Sep;11 (3):299-308.

[90] Radtke F, Wilson A, Stark G, Bauer M, van Meerwijk J, MacDonald HR, et al. Deficient $\mathrm{T}$ cell fate specification in mice with an induced inactivation of Notch1. Immunity. 1999 May;10 (5):547-58.

[91] Mojcik CF, Salomon DR, Chang AC, Shevach EM. Differential expression of integrins on human thymocyte subpopulations. Blood. 1995 Dec 1;86 (11):4206-17.

[92] Salomon DR, Mojcik CF, Chang AC, Wadsworth S, Adams DH, Coligan JE, et al. Constitutive activation of integrin alpha 4 beta 1 defines a unique stage of human thymocyte development. J Exp Med. 1994 May 1;179 (5):1573-84.

[93] Bromley SK, Mempel TR, Luster AD. Orchestrating the orchestrators: chemokines in control of T cell traffic. Nat Immunol. 2008 Sep;9 (9):970-80.

[94] Yasukawa M, Hasegawa A, Sakai I, Ohminami H, Arai J, Kaneko S, et al. Down-regulation of CXCR4 by human herpesvirus 6 (HHV-6) and HHV-7. J Immunol. 1999 May 1;162 (9):5417-22. 
[95] Molon B, Gri G, Bettella M, Gomez-Mouton C, Lanzavecchia A, Martinez AC, et al. T cell costimulation by chemokine receptors. Nat Immunol. 2005 May;6 (5):465-71.

[96] Kumar A, Humphreys TD, Kremer KN, Bramati PS, Bradfield L, Edgar CE, et al. CXCR4 physically associates with the $\mathrm{T}$ cell receptor to signal in $\mathrm{T}$ cells. Immunity. 2006 Aug;25 (2):213-24.

[97] Becker TC, Coley SM, Wherry EJ, Ahmed R. Bone marrow is a preferred site for homeostatic proliferation of memory CD8 T cells. J Immunol. 2005 Feb 1;174 (3):1269-73.

[98] Tokoyoda K, Radbruch A. Signals controlling rest and reactivation of T helper memory lymphocytes in bone marrow. Cell Mol Life Sci. 2012 May;69 (10):1609-13.

[99] Tokoyoda K, Zehentmeier S, Hegazy AN, Albrecht I, Grun JR, Lohning M, et al. Professional memory CD4+T lymphocytes preferentially reside and rest in the bone marrow. Immunity. 2009 May;30 (5):721-30.

[100] Nemoto Y, Kanai T, Takahara M, Oshima S, Nakamura T, Okamoto R, et al. Bone marrow-mesenchymal stem cells are a major source of interleukin-7 and sustain colitis by forming the niche for colitogenic CD4 memory T cells. Gut. 2013 Aug;62 (8): 1142-52.

[101] Hayakawa Y, Smyth MJ. CD27 dissects mature NK cells into two subsets with distinct responsiveness and migratory capacity. J Immunol. 2006 Feb 1;176 (3):1517-24.

[102] Chiossone L, Chaix J, Fuseri N, Roth C, Vivier E, Walzer T. Maturation of mouse NK cells is a 4-stage developmental program. Blood. 2009 May 28;113 (22):5488-96.

[103] Mayol K, Biajoux V, Marvel J, Balabanian K, Walzer T. Sequential desensitization of CXCR4 and S1P5 controls natural killer cell trafficking. Blood. 2011 Nov 3;118 (18): 4863-71.

[104] Sciume G, De Angelis G, Benigni G, Ponzetta A, Morrone S, Santoni A, et al. CX3CR1 expression defines 2 KLRG1+mouse NK-cell subsets with distinct functional properties and positioning in the bone marrow. Blood. 2011 Apr 28;117 (17):4467-75.

[105] Walzer T, Chiossone L, Chaix J, Calver A, Carozzo C, Garrigue-Antar L, et al. Natural killer cell trafficking in vivo requires a dedicated sphingosine 1-phosphate receptor. Nat Immunol. 2007 Dec;8 (12):1337-44.

[106] Tokoyoda K, Egawa T, Sugiyama T, Choi BI, Nagasawa T. Cellular niches controlling B lymphocyte behavior within bone marrow during development. Immunity. 2004 Jun;20 (6):707-18.

[107] Noda M, Omatsu Y, Sugiyama T, Oishi S, Fujii N, Nagasawa T. CXCL12-CXCR4 chemokine signaling is essential for NK-cell development in adult mice. Blood. 2011 Jan $13 ; 117$ (2):451-8.

[108] Cyster JG, Schwab SR. Sphingosine-1-phosphate and lymphocyte egress from lymphoid organs. Annu Rev Immunol. 2012;30:69-94. 
[109] Siedlar M, Rudzki Z, Strach M, Trzyna E, Pituch-Noworolska A, Blaut-Szlosarczyk A, et al. Familial occurrence of warts, hypogammaglobulinemia, infections, and myelokathexis (WHIM) syndrome. Arch Immunol Ther Exp (Warsz). 2008 Nov-Dec;56 (6):419-25.

[110] Beider K, Nagler A, Wald O, Franitza S, Dagan-Berger M, Wald H, et al. Involvement of CXCR4 and IL-2 in the homing and retention of human NK and NK T cells to the bone marrow and spleen of NOD/SCID mice. Blood. 2003 Sep 15;102 (6):1951-8.

[111] Gorlin RJ, Gelb B, Diaz GA, Lofsness KG, Pittelkow MR, Fenyk JR, Jr. WHIM syndrome, an autosomal dominant disorder: clinical, hematological, and molecular studies. Am J Med Genet. 2000 Apr 24;91 (5):368-76.

[112] Beaussant Cohen S, Fenneteau O, Plouvier E, Rohrlich PS, Daltroff G, Plantier I, et al. Description and outcome of a cohort of 8 patients with WHIM syndrome from the French Severe Chronic Neutropenia Registry. Orphanet J Rare Dis. 2012;7:71.

[113] Hernandez PA, Gorlin RJ, Lukens JN, Taniuchi S, Bohinjec J, Francois F, et al. Mutations in the chemokine receptor gene CXCR4 are associated with WHIM syndrome, a combined immunodeficiency disease. Nat Genet. 2003 May;34 (1):70-4.

[114] Balabanian K, Lagane B, Pablos JL, Laurent L, Planchenault T, Verola O, et al. WHIM syndromes with different genetic anomalies are accounted for by impaired CXCR4 desensitization to CXCL12. Blood. 2005 Mar 15;105 (6):2449-57.

[115] Gulino AV, Moratto D, Sozzani S, Cavadini P, Otero K, Tassone L, et al. Altered leukocyte response to CXCL12 in patients with warts hypogammaglobulinemia, infections, myelokathexis (WHIM) syndrome. Blood. 2004 Jul 15;104 (2):444-52.

[116] Kawai T, Malech HL. WHIM syndrome: congenital immune deficiency disease. Curr Opin Hematol. 2009 Jan;16 (1):20-6.

[117] Kallikourdis M, Trovato AE, Anselmi F, Sarukhan A, Roselli G, Tassone L, et al. The CXCR4 mutations in WHIM syndrome impair the stability of the T-cell immunologic synapse. Blood. 2013 Aug 1;122 (5):666-73.

[118] Ingle A, Ghim S, Joh J, Chepkoech I, Bennett Jenson A, Sundberg JP. Novel laboratory mouse papillomavirus (MusPV) infection. Vet Pathol. 2011 Mar;48 (2):500-5.

[119] Handisurya A, Day PM, Thompson CD, Buck CB, Pang YY, Lowy DR, et al. Characterization of Mus musculus papillomavirus 1 infection in situ reveals an unusual pattern of late gene expression and capsid protein localization. J Virol. 2013 Dec;87 (24): 13214-25.

[120] McDermott DH, Liu Q, Ulrick J, Kwatemaa N, Anaya-O'Brien S, Penzak SR, et al. The CXCR4 antagonist plerixafor corrects panleukopenia in patients with WHIM syndrome. Blood. 2011 Nov 3;118 (18):4957-62. 
[121] Dale DC, Bolyard AA, Kelley ML, Westrup EC, Makaryan V, Aprikyan A, et al. The CXCR4 antagonist plerixafor is a potential therapy for myelokathexis, WHIM syndrome. Blood. 2011 Nov 3;118 (18):4963-6.

[122] Ahmad DS, Esmadi M, Steinmann WC. Idiopathic CD4 Lymphocytopenia: Spectrum of opportunistic infections, malignancies, and autoimmune diseases. Avicenna J Med. 2013 Apr;3 (2):37-47.

[123] Smith DK, Neal JJ, Holmberg SD. Unexplained opportunistic infections and CD4+Tlymphocytopenia without HIV infection. An investigation of cases in the United States. The Centers for Disease Control Idiopathic CD4+T-lymphocytopenia Task Force. N Engl J Med. 1993 Feb 11;328 (6):373-9.

[124] Walker UA, Warnatz K. Idiopathic CD4 lymphocytopenia. Curr Opin Rheumatol. 2006 Jul;18 (4):389-95.

[125] Kojima M, Sakurai S, Morita Y, Nakamura N, Sugihara S, Shimano S. EBV (+) B-cell lymphoproliferative disorder associated with subsequent development of Burkitt lymphoma in a patient with idiopathic CD4 (+) T-lymphocytopenia. J Clin Exp Hematop. $2008 \mathrm{Nov}$;48 (2):55-9.

[126] Fierro MT, Savoia P, Quaglino P, Novero D, Bernengo MG. Disseminated Kaposi's sarcoma associated with idiopathic CD4+lymphocytopenia and low dose steroid therapy. Clin Exp Dermatol. 2005 Jul;30 (4):395-7.

[127] Inhoff O, Doerries K, Doerries R, Scharf J, Groden C, Goerdt S, et al. Disseminated cutaneous Kaposi sarcoma and progressive multifocal leukoencephalopathy in a patient with idiopathic CD4+T lymphocytopenia. Arch Dermatol. 2007 May;143 (5): 673-5.

[128] Alisjahbana B, Dinata R, Sutedja E, Suryahudaya I, Soedjana H, Hidajat NN, et al. Disfiguring generalized verrucosis in an indonesian man with idiopathic CD4 lymphopenia. Arch Dermatol. 2010 Jan;146 (1):69-73.

[129] Stetson CL, Rapini RP, Tyring SK, Kimbrough RC. CD4+T lymphocytopenia with disseminated HPV. J Cutan Pathol. 2002 Sep;29 (8):502-5.

[130] Gorska MM, Alam R. A mutation in the human Uncoordinated 119 gene impairs TCR signaling and is associated with CD4 lymphopenia. Blood. 2012 Feb 9;119 (6): 1399-406.

[131] Li FY, Chaigne-Delalande B, Kanellopoulou C, Davis JC, Matthews HF, Douek DC, et al. Second messenger role for $\mathrm{Mg} 2+$ revealed by human $\mathrm{T}$-cell immunodeficiency. Nature. 2011 Jul 28;475 (7357):471-6.

[132] Kuijpers TW, Ijspeert H, van Leeuwen EM, Jansen MH, Hazenberg MD, Weijer KC, et al. Idiopathic CD4+T lymphopenia without autoimmunity or granulomatous disease in the slipstream of RAG mutations. Blood. 2011 Jun 2;117 (22):5892-6. 
[133] Isgro A, Sirianni MC, Gramiccioni C, Mezzaroma I, Fantauzzi A, Aiuti F. Idiopathic CD4+lymphocytopenia may be due to decreased bone marrow clonogenic capability. Int Arch Allergy Immunol. 2005 Apr;136 (4):379-84.

[134] Fruhwirth M, Clodi K, Heitger A, Neu N. Lymphocyte diversity in a 9-year-old boy with idiopathic CD4+T cell lymphocytopenia. Int Arch Allergy Immunol. 2001 May; 125 (1):80-5.

[135] Cervera C, Fernandez-Aviles F, de la Calle-Martin O, Bosch X, Rovira M, Plana M, et al. Non-myeloablative hematopoietic stem cell transplantation in the treatment of severe idiopathic CD4+lymphocytopenia. Eur J Haematol. 2011 Jul;87 (1):87-91.

[136] Laurence J, Mitra D, Steiner M, Lynch DH, Siegal FP, Staiano-Coico L. Apoptotic depletion of CD4+T cells in idiopathic CD4+T lymphocytopenia. J Clin Invest. 1996 Feb 1;97 (3):672-80.

[137] Roger PM, Bernard-Pomier G, Counillon E, Breittmayer JP, Bernard A, Dellamonica P. Overexpression of Fas/CD95 and Fas-induced apoptosis in a patient with idiopathic CD4+T lymphocytopenia. Clin Infect Dis. 1999 May;28 (5):1012-6.

[138] Zonios DI, Falloon J, Bennett JE, Shaw PA, Chaitt D, Baseler MW, et al. Idiopathic CD4+lymphocytopenia: natural history and prognostic factors. Blood. 2008 Jul 15;112 (2):287-94.

[139] Lee PI, Ciccone EJ, Read SW, Asher A, Pitts R, Douek DC, et al. Evidence for translocation of microbial products in patients with idiopathic CD4 lymphocytopenia. J Infect Dis. 2009 Jun 1;199 (11):1664-70.

[140] Malaspina A, Moir S, Chaitt DG, Rehm CA, Kottilil S, Falloon J, et al. Idiopathic CD4+T lymphocytopenia is associated with increases in immature/transitional B cells and serum levels of IL-7. Blood. 2007 Mar 1;109 (5):2086-8.

[141] Puronen CE, Thompson WL, Imamichi H, Beq S, Hodge JN, Rehm C, et al. Decreased interleukin 7 responsiveness of $\mathrm{T}$ lymphocytes in patients with idiopathic CD4 lymphopenia. J Infect Dis. 2012 May 1;205 (9):1382-90.

[142] Bugault F, Benati D, Mouthon L, Landires I, Rohrlich P, Pestre V, et al. Altered responses to homeostatic cytokines in patients with idiopathic CD4 lymphocytopenia. PLoS One. 2013;8 (1):e55570.

[143] Cunningham-Rundles C, Murray HW, Smith JP. Treatment of idiopathic CD4 T lymphocytopenia with IL-2. Clin Exp Immunol. 1999 May;116 (2):322-5.

[144] Scott-Algara D, Balabanian K, Chakrabarti LA, Mouthon L, Dromer F, Didier C, et al. Idiopathic CD4+T-cell lymphocytopenia is associated with impaired membrane expression of the chemokine receptor CXCR4. Blood. 2010 May 6;115 (18):3708-17.

[145] Dighiero G, Follezou JY, Binet JL. Surface immunoglobulins in lymphocytic leukemias. Blood. 1977 Jul;50 (1):179. 
[146] Rai KR, Sawitsky A, Cronkite EP, Chanana AD, Levy RN, Pasternack BS. Clinical staging of chronic lymphocytic leukemia. Blood. 1975 Aug;46 (2):219-34.

[147] Granziero L, Ghia P, Circosta P, Gottardi D, Strola G, Geuna M, et al. Survivin is expressed on CD40 stimulation and interfaces proliferation and apoptosis in B-cell chronic lymphocytic leukemia. Blood. 2001 May 1;97 (9):2777-83.

[148] Damle RN, Batliwalla FM, Ghiotto F, Valetto A, Albesiano E, Sison C, et al. Telomere length and telomerase activity delineate distinctive replicative features of the B-CLL subgroups defined by immunoglobulin V gene mutations. Blood. 2004 Jan 15;103 (2): 375-82.

[149] Messmer BT, Messmer D, Allen SL, Kolitz JE, Kudalkar P, Cesar D, et al. In vivo measurements document the dynamic cellular kinetics of chronic lymphocytic leukemia B cells. J Clin Invest. 2005 Mar;115 (3):755-64.

[150] Rosenwald A, Alizadeh AA, Widhopf G, Simon R, Davis RE, Yu X, et al. Relation of gene expression phenotype to immunoglobulin mutation genotype in $\mathrm{B}$ cell chronic lymphocytic leukemia. J Exp Med. 2001 Dec 3;194 (11):1639-47.

[151] Klein U, Tu Y, Stolovitzky GA, Mattioli M, Cattoretti G, Husson H, et al. Gene expression profiling of $\mathrm{B}$ cell chronic lymphocytic leukemia reveals a homogeneous phenotype related to memory B cells. J Exp Med. 2001 Dec 3;194 (11):1625-38.

[152] Seifert M, Sellmann L, Bloehdorn J, Wein F, Stilgenbauer S, Durig J, et al. Cellular origin and pathophysiology of chronic lymphocytic leukemia. J Exp Med. 2012 Nov 19;209 (12):2183-98.

[153] Herve M, Xu K, Ng YS, Wardemann H, Albesiano E, Messmer BT, et al. Unmutated and mutated chronic lymphocytic leukemias derive from self-reactive B cell precursors despite expressing different antibody reactivity. J Clin Invest. 2005 Jun;115 (6): 1636-43.

[154] Mohle R, Failenschmid C, Bautz F, Kanz L. Overexpression of the chemokine receptor CXCR4 in B cell chronic lymphocytic leukemia is associated with increased functional response to stromal cell-derived factor-1 (SDF-1). Leukemia. 1999 Dec;13 (12): 1954-9.

[155] Burger JA, Zvaifler NJ, Tsukada N, Firestein GS, Kipps TJ. Fibroblast-like synoviocytes support B-cell pseudoemperipolesis via a stromal cell-derived factor-1-and CD106 (VCAM-1)-dependent mechanism. J Clin Invest. 2001 Feb;107 (3):305-15.

[156] Lagneaux L, Delforge A, Bron D, De Bruyn C, Stryckmans P. Chronic lymphocytic leukemic B cells but not normal B cells are rescued from apoptosis by contact with normal bone marrow stromal cells. Blood. 1998 Apr 1;91 (7):2387-96.

[157] Burger JA, Gribben JG. The microenvironment in chronic lymphocytic leukemia (CLL) and other B cell malignancies: Insight into disease biology and new targeted therapies. Semin Cancer Biol. 2014 Feb;24:71-81. 
[158] de la Fuente MT, Casanova B, Moyano JV, Garcia-Gila M, Sanz L, Garcia-Marco J, et al. Engagement of alpha4beta1 integrin by fibronectin induces in vitro resistance of $B$ chronic lymphocytic leukemia cells to fludarabine. J Leukoc Biol. 2002 Mar;71 (3): 495-502.

[159] Tsukada N, Burger JA, Zvaifler NJ, Kipps TJ. Distinctive features of "nurselike" cells that differentiate in the context of chronic lymphocytic leukemia. Blood. 2002 Feb 1;99 (3):1030-7.

[160] Kumar CC. Signaling by integrin receptors. Oncogene. 1998 Sep 17;17 (11 Reviews): 1365-73.

[161] Bagnara D, Kaufman MS, Calissano C, Marsilio S, Patten PE, Simone R, et al. A novel adoptive transfer model of chronic lymphocytic leukemia suggests a key role for $\mathrm{T}$ lymphocytes in the disease. Blood. 2011 May 19;117 (20):5463-72.

[162] Furman RR, Asgary Z, Mascarenhas JO, Liou HC, Schattner EJ. Modulation of NFkappa B activity and apoptosis in chronic lymphocytic leukemia B cells. J Immunol. 2000 Feb 15;164 (4):2200-6.

[163] Ghia P, Strola G, Granziero L, Geuna M, Guida G, Sallusto F, et al. Chronic lymphocytic leukemia B cells are endowed with the capacity to attract CD4+, CD40L+T cells by producing CCL22. Eur J Immunol. 2002 May;32 (5):1403-13.

[164] Chilosi M, Pizzolo G, Caligaris-Cappio F, Ambrosetti A, Vinante F, Morittu L, et al. Immunohistochemical demonstration of follicular dendritic cells in bone marrow involvement of B-cell chronic lymphocytic leukemia. Cancer. 1985 Jul 15;56 (2):328-32.

[165] Burger M, Hartmann T, Krome M, Rawluk J, Tamamura H, Fujii N, et al. Small peptide inhibitors of the CXCR4 chemokine receptor (CD184) antagonize the activation, migration, and antiapoptotic responses of CXCL12 in chronic lymphocytic leukemia B cells. Blood. 2005 Sep 1;106 (5):1824-30.

[166] Burger JA, Ghia P, Rosenwald A, Caligaris-Cappio F. The microenvironment in mature B-cell malignancies: a target for new treatment strategies. Blood. 2009 Oct 15;114 (16):3367-75.

[167] Lankester AC, van Schijndel GM, van der Schoot CE, van Oers MH, van Noesel CJ, van Lier RA. Antigen receptor nonresponsiveness in chronic lymphocytic leukemia B cells. Blood. 1995 Aug 1;86 (3):1090-7.

[168] Stevenson FK, Krysov S, Davies AJ, Steele AJ, Packham G. B-cell receptor signaling in chronic lymphocytic leukemia. Blood. 2011 Oct 20;118 (16):4313-20.

[169] Vlad A, Deglesne PA, Letestu R, Saint-Georges S, Chevallier N, Baran-Marszak F, et al. Down-regulation of CXCR4 and CD62L in chronic lymphocytic leukemia cells is triggered by B-cell receptor ligation and associated with progressive disease. Cancer Res. 2009 Aug 15;69 (16):6387-95. 
[170] Stamatopoulos B, Meuleman N, De Bruyn C, Pieters K, Mineur P, Le Roy C, et al. AMD3100 disrupts the cross-talk between chronic lymphocytic leukemia cells and a mesenchymal stromal or nurse-like cell-based microenvironment: pre-clinical evidence for its association with chronic lymphocytic leukemia treatments. Haematologica. 2012 Apr;97 (4):608-15.

[171] Herishanu Y, Perez-Galan P, Liu D, Biancotto A, Pittaluga S, Vire B, et al. The lymph node microenvironment promotes B-cell receptor signaling, NF-kappaB activation, and tumor proliferation in chronic lymphocytic leukemia. Blood. 2011 Jan 13;117 (2): 563-74.

[172] Lannutti BJ, Meadows SA, Herman SE, Kashishian A, Steiner B, Johnson AJ, et al. CAL-101, a p110delta selective phosphatidylinositol-3-kinase inhibitor for the treatment of B-cell malignancies, inhibits PI3K signaling and cellular viability. Blood. 2011 Jan 13;117 (2):591-4.

[173] Owen RG, Treon SP, Al-Katib A, Fonseca R, Greipp PR, McMaster ML, et al. Clinicopathological definition of Waldenstrom's macroglobulinemia: consensus panel recommendations from the Second International Workshop on Waldenstrom's Macroglobulinemia. Semin Oncol. 2003 Apr;30 (2):110-5.

[174] Treon SP, Hunter ZR, Aggarwal A, Ewen EP, Masota S, Lee C, et al. Characterization of familial Waldenstrom's macroglobulinemia. Ann Oncol. 2006 Mar;17 (3):488-94.

[175] Ngo HT, Leleu X, Lee J, Jia X, Melhem M, Runnels J, et al. SDF-1/CXCR4 and VLA-4 interaction regulates homing in Waldenstrom macroglobulinemia. Blood. $2008 \mathrm{Jul}$ 1;112 (1):150-8.

[176] Jung MJ, Rho JK, Kim YM, Jung JE, Jin YB, Ko YG, et al. Upregulation of CXCR4 is functionally crucial for maintenance of stemness in drug-resistant non-small cell lung cancer cells. Oncogene. 2013 Jan 10;32 (2):209-21.

[177] Ostrow RS, Bender M, Niimura M, Seki T, Kawashima M, Pass F, et al. Human papillomavirus DNA in cutaneous primary and metastasized squamous cell carcinomas from patients with epidermodysplasia verruciformis. Proc Natl Acad Sci U S A. 1982 Mar;79 (5):1634-8.

[178] Eliezri YD, Silverstein SJ, Nuovo GJ. Occurrence of human papillomavirus type 16 DNA in cutaneous squamous and basal cell neoplasms. J Am Acad Dermatol. 1990 Nov;23 (5 Pt 1):836-42.

[179] Hahn A, Loning T, Hoos A, Henke P. Immunohistochemistry (S 100, KL 1) and human papillomavirus DNA hybridization on morbus Bowen and bowenoid papulosis. Virchows Arch A Pathol Anat Histopathol. 1988;413 (2):113-22.

[180] Bryant P, Davies P, Wilson D. Detection of human papillomavirus DNA in cancer of the urinary bladder by in situ hybridisation. Br J Urol. 1991 Jul;68 (1):49-52. 
[181] Schneider A, Oltersdorf T, Schneider V, Gissmann L. Distribution pattern of human papilloma virus 16 genome in cervical neoplasia by molecular in situ hybridization of tissue sections. Int J Cancer. 1987 Jun 15;39 (6):717-21.

[182] Fukamachi H, Seol HS, Shimada S, Funasaka C, Baba K, Kim JH, et al. CD49f (high) cells retain sphere-forming and tumor-initiating activities in human gastric tumors. PLoS One. 2013;8 (8):e72438.

[183] Al-Hajj M, Wicha MS, Benito-Hernandez A, Morrison SJ, Clarke MF. Prospective identification of tumorigenic breast cancer cells. Proc Natl Acad Sci U S A. 2003 Apr 1;100 (7):3983-8.

[184] Singh SK, Clarke ID, Terasaki M, Bonn VE, Hawkins C, Squire J, et al. Identification of a cancer stem cell in human brain tumors. Cancer Res. 2003 Sep 15;63 (18):5821-8.

[185] Collins AT, Berry PA, Hyde C, Stower MJ, Maitland NJ. Prospective identification of tumorigenic prostate cancer stem cells. Cancer Res. 2005 Dec 1;65 (23):10946-51.

[186] O'Brien CA, Pollett A, Gallinger S, Dick JE. A human colon cancer cell capable of initiating tumour growth in immunodeficient mice. Nature. 2007 Jan 4;445 (7123): 106-10.

[187] Ricci-Vitiani L, Lombardi DG, Pilozzi E, Biffoni M, Todaro M, Peschle C, et al. Identification and expansion of human colon-cancer-initiating cells. Nature. 2007 Jan 4;445 (7123):111-5

[188] Li C, Heidt DG, Dalerba P, Burant CF, Zhang L, Adsay V, et al. Identification of pancreatic cancer stem cells. Cancer Res. 2007 Feb 1;67 (3):1030-7.

[189] Prince ME, Sivanandan R, Kaczorowski A, Wolf GT, Kaplan MJ, Dalerba P, et al. Identification of a subpopulation of cells with cancer stem cell properties in head and neck squamous cell carcinoma. Proc Natl Acad Sci U S A. 2007 Jan 16;104 (3):973-8.

[190] Yang W, Yan HX, Chen L, Liu Q, He YQ, Yu LX, et al. Wnt/beta-catenin signaling contributes to activation of normal and tumorigenic liver progenitor cells. Cancer Res. 2008 Jun 1;68 (11):4287-95.

[191] Vicari AP, Caux C. Chemokines in cancer. Cytokine Growth Factor Rev. 2002 Apr;13 (2):143-54.

[192] Balkwill F. Cancer and the chemokine network. Nat Rev Cancer. 2004 Jul;4 (7):540-50.

[193] D'Alterio C, Barbieri A, Portella L, Palma G, Polimeno M, Riccio A, et al. Inhibition of stromal CXCR4 impairs development of lung metastases. Cancer Immunol Immunother. 2012 Oct;61 (10):1713-20.

[194] Wei S, Kryczek I, Edwards RP, Zou L, Szeliga W, Banerjee M, et al. Interleukin-2 administration alters the CD4+FOXP3+T-cell pool and tumor trafficking in patients with ovarian carcinoma. Cancer Res. 2007 Aug 1;67 (15):7487-94. 
[195] Wald O, Izhar U, Amir G, Avniel S, Bar-Shavit Y, Wald H, et al. CD4+CXCR4highCD69+T cells accumulate in lung adenocarcinoma. J Immunol. 2006 Nov 15;177 (10):6983-90.

[196] Shimizu Y, Dobashi K, Imai H, Sunaga N, Ono A, Sano T, et al. CXCR4+FOXP3+CD25+lymphocytes accumulate in CXCL12-expressing malignant pleural mesothelioma. Int J Immunopathol Pharmacol. 2009 Jan-Mar;22 (1):43-51.

[197] Kotsianidis I, Bouchliou I, Nakou E, Spanoudakis E, Margaritis D, Christophoridou $\mathrm{AV}$, et al. Kinetics, function and bone marrow trafficking of CD4+CD25+FOXP3+regulatory $\mathrm{T}$ cells in myelodysplastic syndromes (MDS). Leukemia. 2009 Mar;23 (3): 510-8.

[198] Yan M, Jene N, Byrne D, Millar EK, O'Toole SA, McNeil CM, et al. Recruitment of regulatory T cells is correlated with hypoxia-induced CXCR4 expression, and is associated with poor prognosis in basal-like breast cancers. Breast Cancer Res. 2011;13 (2):R47.

[199] Curiel TJ, Coukos G, Zou L, Alvarez X, Cheng P, Mottram P, et al. Specific recruitment of regulatory $\mathrm{T}$ cells in ovarian carcinoma fosters immune privilege and predicts reduced survival. Nat Med. 2004 Sep;10 (9):942-9.

[200] Pistoia V, Corcione A, Dallegri F, Ottonello L. Lymphoproliferative disorders and chemokines. Curr Drug Targets. 2006 Jan;7 (1):81-90.

[201] Chong BF, Mohan C. Targeting the CXCR4/CXCL12 axis in systemic lupus erythematosus. Expert Opin Ther Targets. 2009 Oct;13 (10):1147-53.

[202] Biajoux V, Bignon A, Freitas C, Martinez V, Thelen M, Lima G, et al. Expression of CXCL12 receptors in B cells from Mexican Mestizos patients with systemic Lupus erythematosus. J Transl Med. 2012;10:251.

[203] Duda DG, Kozin SV, Kirkpatrick ND, Xu L, Fukumura D, Jain RK. CXCL12 (SDF1alpha)-CXCR4/CXCR7 pathway inhibition: an emerging sensitizer for anticancer therapies? Clin Cancer Res. 2011 Apr 15;17 (8):2074-80.

[204] Debnath B, Xu S, Grande F, Garofalo A, Neamati N. Small molecule inhibitors of CXCR4. Theranostics. 2013;3 (1):47-75.

[205] Bachelerie F, Ben-Baruch A, Burkhardt AM, Combadiere C, Farber JM, Graham GJ, et al. International Union of Pharmacology. LXXXIX. Update on the extended family of chemokine receptors and introducing a new nomenclature for atypical chemokine receptors. Pharmacol Rev. 2014 Jan;66 (1):1-79.

[206] Calandra G, Bridger G, Fricker S. CXCR4 in clinical hematology. Curr Top Microbiol Immunol. 2010;341:173-91. 
[207] McDermott DH, Liu Q, Velez D, Lopez L, Anaya-O'Brien S, Ulrick J, et al. A phase 1 clinical trial of long-term, low-dose treatment of WHIM syndrome with the CXCR4 antagonist plerixafor. Blood. 2014 Feb 12.

[208] Melo Rde C, Longhini AL, Bigarella CL, Baratti MO, Traina F, Favaro P, et al. CXCR7 Is Highly Expressed in Acute Lymphoblastic Leukemia and Potentiates CXCR4 Response to CXCL12. PLoS One. 2014;9 (1):e85926.

[209] Torossian F, Anginot A, Chabanon A, Clay D, Guerton B, Desterke C, et al. CXCR7 participates in CXCL12-induced CD34+cell cycling through beta-arrestin-dependent Akt activation. Blood. 2014 Jan 9;123 (2):191-202. 
